Supplementary information for the paper under the title:

\title{
Organo-Catalyzed Cyclizations of $\pi$-Allylpalladium Complexes: a New Method for the Construction of Five- and Six-Membered Rings
}

by: Filip Bihelovic, ${ }^{a}$ Radomir Matovic, ${ }^{b}$ Bojan Vulovic ${ }^{a}$ and Radomir N. Saicic ${ }^{\mathrm{a}, \mathrm{b}, \mathrm{c}, *}$

a) Faculty of Chemistry, University of Belgrade, Studentski trg 16, P. O. B. 158, 11000 Belgrade, Serbia, Fax: (+381) 112636 061, E-mail: rsaicic@chem.bg.ac.yu;

b) ICTM-Center for Chemistry, Njegoseva 12, Belgrade;

c) l'Institut de Chimie des Substances Naturelles, CNRS, Gif-sur-Yvette, France

\section{Content:}

General experimetal - - - - - - - - - - - - - S S2

1. Preparation of precursors - - - - - - - - - - - - - S3

Scheme S1: Preparation of the precursors described in this _ - _ - - - S3 Supplementary information - graphical representation

1.1. (E)-8-bromooct-6-enal 4 - - - - - - - - - - - - - - - - - S4

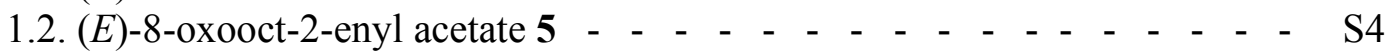

1.3. 8,8-dimethoxyoct-1-en-3-ol 19 - - - - - - - - - - - - S5

1.4. 8-oxooct-1-en-3-yl acetate 6 - - - - - - - - - - - - - - S5

1.5. $N$-(2-(1,3-dioxolan-2-yl)ethyl)-4-methylbenzenesulfonamide 21 - - - - - S6

1.6. (E)-N-(2-(1,3-dioxolan-2-yl)ethyl)-N-(4-bromobut-2-enyl)- - - - - $\mathrm{S} 7$ -4-methylbenzenesulfonamide 22

1.7. (E)- $N$-(4-bromobut-2-enyl)-4-methyl- $N$-(3-oxopropyl)benzenesulfonamide 8 S7

1.8. (E)-ethyl 9,9-dimethoxynon-2-enoate 24 - - - - - - - - - S8

1.9. (E)-9,9-dimethoxynon-2-en-1-ol 25 - - - - - - - - - - S8

1.10. (E)-9-bromonon-7-enal 9 - - - - - - - - - - - - - S9

1.11. (E)-9-oxonon-2-enyl acetate 10 - - - - - - - - - - S9

2. Organo-catalyzed cyclizations of $\pi$-allylpalladium intermediates - - - - S10

2.1. Diastereoselective cyclizations - - - - - - - - - - - - - S10

2.1.1. General procedure for the cyclization: - - - - - - - - - - - S10 trans-2-vinylcyclopentanecarbaldehyde 12 (Method A)

2.1.2. General procedure for the cyclization: - - - - - - - - - - S11 trans-2-vinylcyclopentanecarbaldehyde 12 (Method B) 
2.1.3. Trans-2-vinylcyclopentanecarbaldehyde 12 from the - - - - - - S11 regioisomeric precursor 6

2.1.4. Diethyl trans-3-formyl-4-vinylcyclopentane-1,1-dicarboxylate 13 - - - S11

2.1.5. Trans-1-tosyl-4-vinylpyrrolidine-3-carbaldehyde 14 - - - - - - S12

2.1.6. Trans-2-vinylcyclohexanecarbaldehyde 15 - - - - - - - - S S12

2.1.7. Trans-2-vinylcyclohexanecarbaldehyde 15 (from 10) - - - - - - - S13

2.2. Enantioselective cyclizations - - - - - - - - - - - - $-\mathrm{S} 13$

2.2.1. (-)-Diethyl trans-3-formyl-4-vinylcyclopentane-1,1-dicarboxylate (-)-13 S13

2.2.2. (-)-Trans-1-tosyl-4-vinylpyrrolidine-3-carbaldehyde (-)-14 - - - - - S14

2.2.2.1. Determination of the optical purity of (-)-14 - - - - - - - - S15

2.2.2.2. (Trans-1-tosyl-4-vinylpyrrolidin-3-yl)methanol 26 - - - - - - - S15

2.2.2.3. Mosher's ester of Trans-1-tosyl-4-vinylpyrrolidin-3-yl)methanol 27 - - S16

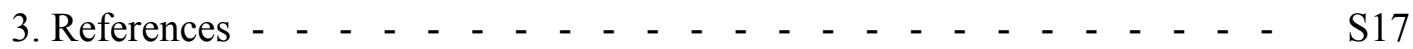

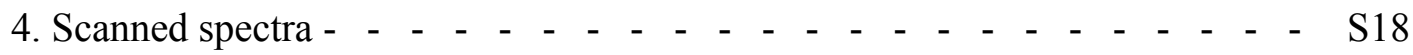

General experimental

All chromatographic separations ${ }^{1}$ were performed on Silica, 10-18, 60A, ICN Biomedicals. Standard techniques were used for the purification of reagents and solvents. ${ }^{2}$ NMR spectra were recorded on a Varian Gemini 200, $\left({ }^{1} \mathrm{H}\right.$ NMR at $200 \mathrm{MHz}$, ${ }^{13} \mathrm{C}$ NMR at $50 \mathrm{MHz}$, for samples in deuterated chloroform), and on Bruker Avance III $500\left({ }^{1} \mathrm{H}\right.$ NMR at $500 \mathrm{MHz},{ }^{13} \mathrm{C} \mathrm{NMR}$ at $125 \mathrm{MHz},{ }^{19} \mathrm{~F}$ at $\left.470 \mathrm{MHz}\right)$. Chemical shifts are expressed in ppm $(\delta)$ using tetramethylsilane as internal standard, coupling constants $(J)$ are in Hz. IR spectra were recorded on a Nicolet 6700 FT instrument, and are expressed in $\mathrm{cm}^{-1}$. Mass spectra were obtained on Agilent technologies 6210 TOF LC/MS instrument (LC: series 1200). Gas chromatography analyses were performed on HP5890 instrument equipped with Split/Splitless injector (split 1:99), operated at $244{ }^{\circ} \mathrm{C}$; Column: J\&W Scientific HP-Chiral 20, $30 \mathrm{~m}, 0.25 \mathrm{~mm}$ i. d., $0.25 \mu \mathrm{m}$ film; Carrier gas hydrogen, $1 \mathrm{~mL} / \mathrm{min}$ measured at $210^{\circ} \mathrm{C}$. Microanalyses were performed at the Vario EL III instrument CHNOS Elementar Analyzer, Elementar Analysensysteme GmbH, HanauGermany. Melting points were determined on a Kofler hot-stage apparatus and are uncorrected. Compounds $7,{ }^{3} \mathbf{1 7},{ }^{4} \mathbf{1 8},{ }^{5} \mathbf{2 0}^{6}$ and $\mathbf{2 3}^{7}$ were prepared according to literature procedures. 


\section{Preparation of precursors}

Scheme S1: Preparation of the precursors described in this Supplementary information<smiles>COC(CCCC/C=C/CO)CCCCC(OC)OC</smiles>

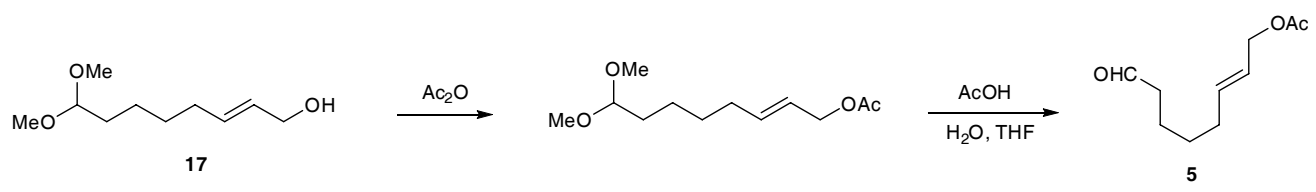

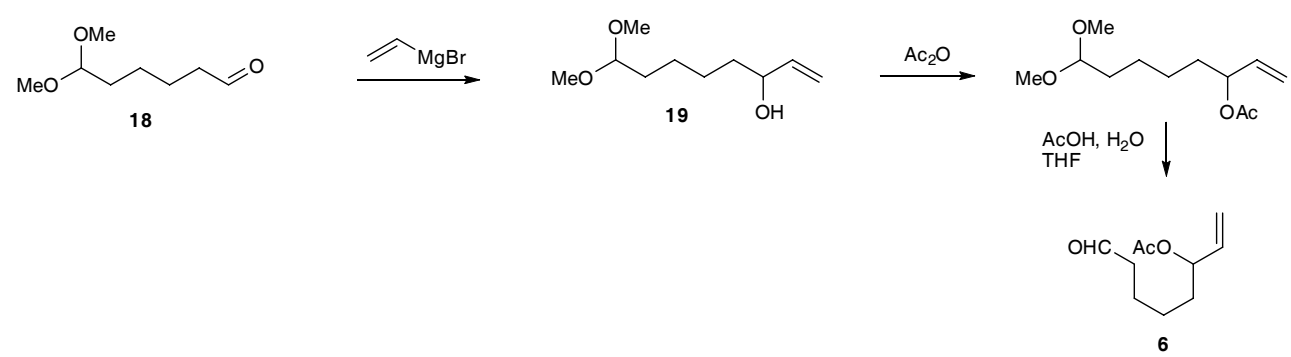

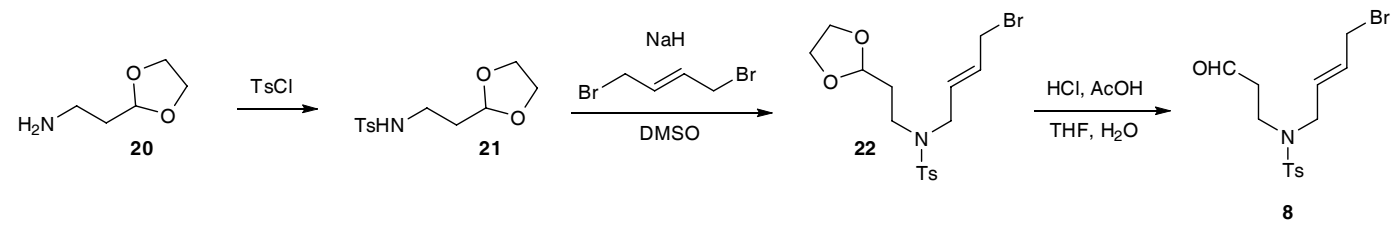<smiles>CCOC(=O)CP(=O)(OCC)OCC</smiles><smiles>CCOC(=O)C=CCCCCCC(OC)OC</smiles>

DIBAL

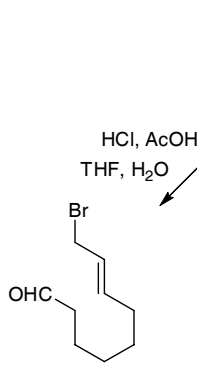

9<smiles>COC(CCCCCC=CCO)OC</smiles>

25 $\begin{gathered}\mathrm{HCl}, \mathrm{AcOH} \\ \mathrm{THF}, \mathrm{H}_{2} \mathrm{O}\end{gathered}$

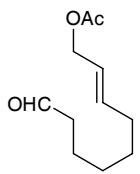

10 


\section{1. (E)-8-bromooct-6-enal (4)}

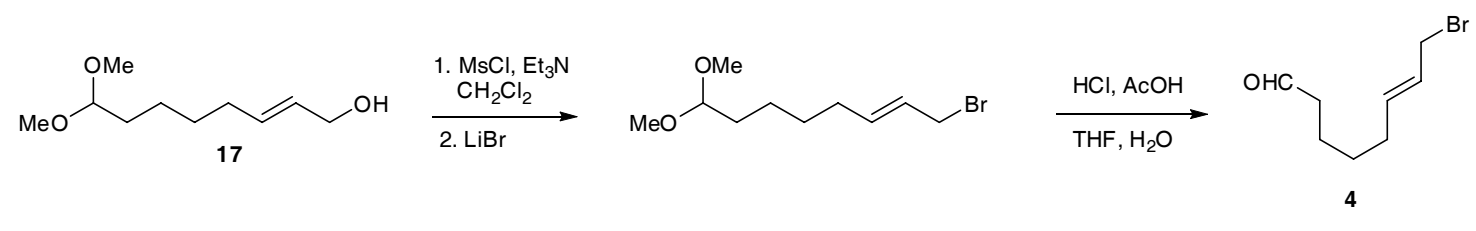

Mesyl chloride (94 mg; $68 \mu \mathrm{L} ; 0.83 \mathrm{mmol})$ was added dropwise to a cold $\left(-15{ }^{\circ} \mathrm{C}\right)$ solution of triethylamine (96 mg; $137 \mu \mathrm{L} ; 0.957 \mathrm{mmol})$ and alcohol $17^{4}(120 \mathrm{mg} ; 0.638$ mmol) in dichloromethane $(1.5 \mathrm{~mL})$, with stirring, under an argon atmosphere. Upon completion, the reaction mixture was diluted with diethyl ether $(10 \mathrm{~mL})$ and saturated aq. $\mathrm{NaHCO}_{3}(10 \mathrm{~mL})$, and the mixture was stirred for $20 \mathrm{~min}$. The organic layer was separated, and the aqueous layer was extracted with dichloromethane $(2 \times 120 \mathrm{~mL})$. The combined organic extract was washed with water, dried over anh. $\mathrm{MgSO}_{4}$ and concentrated under reduced pressure, to give $156 \mathrm{mg}$ (92\%) of the crude mesylate, which was used in the next step without further purification.

A solution of $\mathrm{LiBr}(457 \mathrm{mg} ; 5.3 \mathrm{mmol})$ in THF $(2 \mathrm{~mL})$ was added to a cold $\left(0{ }^{\circ} \mathrm{C}\right)$ solution of the mesylate (from the previous step; $140 \mathrm{mg}$; $0.53 \mathrm{mmol}$ ) in dichloromethane $(1.5 \mathrm{~mL})$. The reaction mixture was stirred for $20 \mathrm{~min}$. at r. t., followed by dilution with water and extraction with dichloromethane $(2 \times 20 \mathrm{~mL})$. The organic extract was washed with water, dried over anh. $\mathrm{MgSO}_{4}$ and concentrated under reduced pressure. The crude product was purified by dry-flash chromatography (eluent: $10 \%$ ethyl acetate in petroleum-ether), to give $100 \mathrm{mg}(76 \%)$ of the acetal which was immediately used in the next step.

A solution of the acetal (from the previous step; $100 \mathrm{mg} ; 0.398 \mathrm{mmol}$ ) in a mixture of solvents $\left(\mathrm{THF} / \mathrm{H}_{2} \mathrm{O} / \mathrm{AcOH}=1 / 1 / 1\right.$, total volume $\left.2 \mathrm{~mL}\right)$ was stirred at $\mathrm{r}$. t. for $30 \mathrm{~min}$. Upon completion, the reaction mixture was extracted with dichloromethane $(2 \times 20 \mathrm{~mL})$, and the extract was washed with sat. aq. $\mathrm{NaHCO}_{3}$ and water, dried over anh. $\mathrm{MgSO}_{4}$ and concentrated under reduced pressure. Purification of the crude material by dry-flash chromatography (eluent: 10\% EtOAc in petroleum-ether) afforded $60 \mathrm{mg}(74 \%)$ of the title compound 4, as a colorless oil. Spectral data for 4: IR film: 2932, 2858, 2720, 1724, 1660, 1437, 1359, 1204, 1125, 1082, 968, 735, 673. ${ }^{1} \mathrm{H}$ NMR: 9.77 (t, $\left.J=2,1 \mathrm{H}\right), 5.76-$ $5.65(\mathrm{~m}, 2 \mathrm{H}), 3.92(\mathrm{~d}, J=6.6,2 \mathrm{H}), 2,45\left(\mathrm{dt}, J^{l}=5.4, J^{2}=1.6,2 \mathrm{H}\right), 2.22-1.96(\mathrm{~m}, 2 \mathrm{H})$, 1.72-1.55 (m, 2H), 1.52-1.35 (m, 2H). ${ }^{13} \mathrm{C}$ NMR: $202.5(\mathrm{C}), 135.7(\mathrm{CH}), 126.9(\mathrm{C}), 43.6$ $\left(\mathrm{CH}_{2}\right), 33.3\left(\mathrm{CH}_{2}\right), 31.7\left(\mathrm{CH}_{2}\right), 28.2\left(\mathrm{CH}_{2}\right), 21.4\left(\mathrm{CH}_{2}\right)$.

\section{2. (E)-8-oxooct-2-enyl acetate (5)}

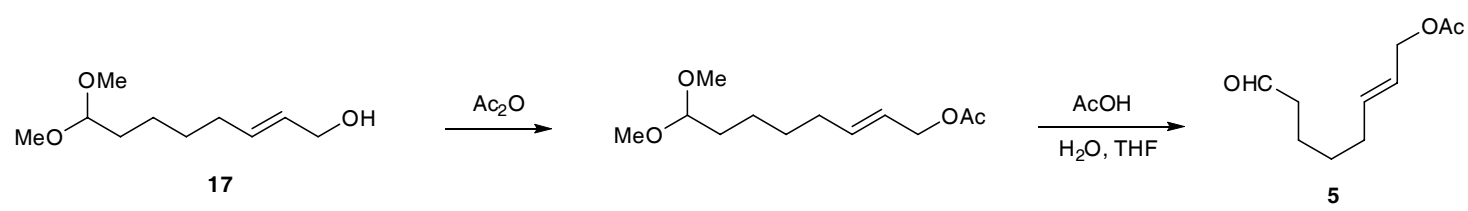

Acetic anhydride $(240 \mu \mathrm{L} ; 2.35 \mathrm{mmol})$ was added dropwise to a cold $\left(0{ }^{\circ} \mathrm{C}\right)$ solution of alcohol $17^{4}$ (295 mg; $\left.1.57 \mathrm{mmol}\right)$, triethylamine $(435 \mu \mathrm{L} ; 3.13 \mathrm{mmol})$ and DMAP (cat. 
amount) in dichloromethane $(3 \mathrm{~mL})$. After $10 \mathrm{~min}$. the reaction mixture was diluted with dichloromethane, washed with water, sat. aq. $\mathrm{NaHCO}_{3}$ and water, dried over anh. $\mathrm{MgSO}_{4}$ and concentrated under reduced pressure. Purification by dry-flash chromatography (eluent: $10 \%$ ethyl acetate in petroleum-ether) afforded $300 \mathrm{mg}(83 \%)$ of the acetate, which was immediately used in the next step.

A solution of the acetate (from the previous step; $275 \mathrm{mg} ; 1.19 \mathrm{mmol}$ ), THF (1 mL), $\mathrm{H}_{2} \mathrm{O}$ $(1 \mathrm{~mL}), \mathrm{AcOH}(1 \mathrm{~mL})$ and one drop of $18 \% \mathrm{HCl}$ was stirred at $\mathrm{r}$. $\mathrm{t}$. for $1 \mathrm{~h}$. The reaction mixture was extracted with dichloromethane, washed with sat. aq. $\mathrm{NaHCO}_{3}$ and water, dried over anh. $\mathrm{MgSO}_{4}$ and concentrated under reduced pressure. Purification by dryflash chromatography (eluent: $10 \%$ ethyl acetate in petroleum-ether) afforded $160 \mathrm{mg}$ (75\%) of the title compound 5, as a colorless oil. Spectral data for 5: IR film: 2935,2860 , 2724, 1739, 1638, 1446, 1383, 1364, 1233, 1082, 1026, 970. ${ }^{1} \mathrm{H}$ NMR: 9.77 (t, $J=1.7$, $\mathrm{H})$; 5.83-5.69 (m, H), 5.64-5.50 (m, H), $4.50(\mathrm{~d}, J=5.8,2 \mathrm{H}), 2.44\left(\mathrm{dt}, J^{l}=7.1, J^{2}=1.7\right.$, $2 \mathrm{H}), 2.14-2.07(\mathrm{~m}, 2 \mathrm{H}), 2.06(\mathrm{~s}, 3 \mathrm{H}), 1.72-1.52(\mathrm{~m}, 2 \mathrm{H}), 1.5-1.36(\mathrm{~m}, 2 \mathrm{H}) .{ }^{13} \mathrm{C} \mathrm{NMR}$ : $202.5(\mathrm{CH}), 170.4(\mathrm{C}), 136.0(\mathrm{CH}), 124.4(\mathrm{CH}), 65.1\left(\mathrm{CH}_{2}\right), 43.6\left(\mathrm{CH}_{2}\right), 31.9\left(\mathrm{CH}_{2}\right), 28.3$ $\left(\mathrm{CH}_{2}\right), 21.5\left(\mathrm{CH}_{2}\right), 21.0\left(\mathrm{CH}_{3}\right)$. HRMS (ESI): calcd for $\mathrm{C}_{10} \mathrm{H}_{16} \mathrm{O}_{3} \mathrm{Na}[\mathrm{M}+\mathrm{Na}]^{+}$: 207.0992, found 207.0990.

\subsection{8,8-dimethoxyoct-1-en-3-ol (19)}<smiles>COC(C)CCCCC=O</smiles><smiles>CC=C[Mg]Br</smiles><smiles>C=CC(O)CCCCC(OC)OC</smiles>

Vinylmagnesiumn bromide $(2.15 \mathrm{~mL}$ of the $0.7 \mathrm{M}$ solution in THF; $1.5 \mathrm{mmol})$ was added dropwise to a cold $\left(-78^{\circ} \mathrm{C}\right)$ solution of aldehyde $18^{5}(160 \mathrm{mg} ; 1 \mathrm{mmol})$ in THF $(4 \mathrm{~mL})$, with stirring, under an argon atmosphere. After $10 \mathrm{~min}$., the reaction mixture was diluted with water $(3 \mathrm{~mL})$ and extracted with dichloromethane. The organic extract was dried over anh. $\mathrm{MgSO}_{4}$ and concentrated under reduced pressure. Purification by dry-flash chromatography (eluent: $20 \%$ ethyl acetate in petroleum-ether) afforded $142 \mathrm{mg}(76 \%)$ of the title compound 19, as a colorless oil. Spectral data for 19: ${ }^{1} \mathrm{H}$ NMR: 5.87-5.78 $(\mathrm{m}, \mathrm{H})$, 5.24-5.03 (m, 2H), $4.38(\mathrm{t}, J=5.6, \mathrm{H}), 4.18-4.01(\mathrm{~m}, \mathrm{H}), 3.35(\mathrm{~s}, 6 \mathrm{H}), 2.02$ (s, broad, H), 1.75-1.42 (m, 4H), 1.40-1.25 (m,4H). ${ }^{13} \mathrm{C}$ NMR: $141.2(\mathrm{CH}), 114.4\left(\mathrm{CH}_{2}\right), 104.3(\mathrm{CH})$, $72.8(\mathrm{CH}), 52.4(\mathrm{CH}), 36.7\left(\mathrm{CH}_{2}\right), 32.2\left(\mathrm{CH}_{2}\right), 25.0\left(\mathrm{CH}_{2}\right), 24.7\left(\mathrm{CH}_{2}\right)$.

\subsection{8-oxooct-1-en-3-yl acetate (6)}

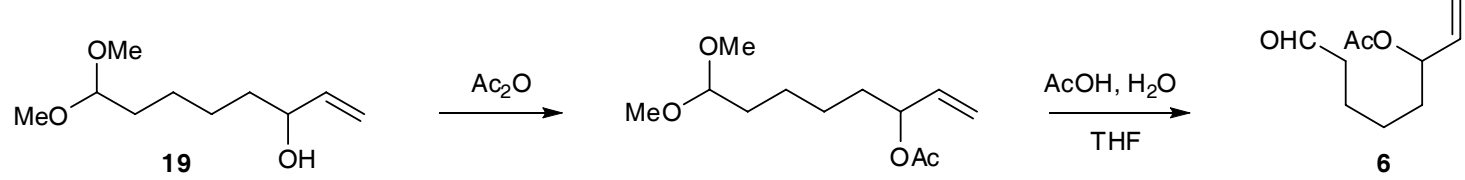

Acetic anhydride $(116 \mathrm{mg} ; 107 \mu \mathrm{L} ; 1.14 \mathrm{mmol})$ was added dropwise to a cold $\left(0{ }^{\circ} \mathrm{C}\right)$ solution of alcohol 19 (142 $\mathrm{mg} ; 0.755 \mathrm{mmol})$, triethylamine $(152 \mathrm{mg} ; 210 \mu \mathrm{L} ; 1.51$ 
mmol) and DMAP (cat. amount) in dichloromethane $(2 \mathrm{~mL})$. After $20 \mathrm{~min}$. the reaction mixture was diluted with dichloromethane, washed with water, dried over anh. $\mathrm{MgSO}_{4}$, concentrated under reduced pressure to give $147 \mathrm{mg}$ of the crude acetate which was used in the next step without further purification.

The crude product (from the previous step) was dissolved in a mixture of solvents (THF: $\mathrm{H}_{2} \mathrm{O}: \mathrm{AcOH}=1: 1$, total volume $3 \mathrm{~mL}$ ), a drop of $18 \% \mathrm{HCl}$ was added and the reaction mixture was stirred for $1 \mathrm{~h}$ at $\mathrm{r}$. $\mathrm{t}$. The mixture was extracted with dichloromethane, washed with water, dried over anh. $\mathrm{MgSO}_{4}$ and concentrated under reduced pressure. Purification of the residue by dry-flash chromatography (eluent: $10 \%$ ethyl acetate in petroleum ether) afforded $102 \mathrm{mg}(86 \%)$ of the title compound $\mathbf{6}$, as a colorless oil. Spectral data for 6: IR film: 3088, 2942, 2864, 2722, 1734, 1646, 1412, 1372, 1240, 1020, 991, 931, 735. ${ }^{1} \mathrm{H}$ NMR: 9.76 (t, $\left.J=1.8, \mathrm{H}\right), 5.85-5.68(\mathrm{~m}, \mathrm{H}), 5.26-5.14(\mathrm{~m}$, $3 \mathrm{H}), 2.44\left(\mathrm{dt}, J^{1}=5.6, J^{2}=1.4,2 \mathrm{H}\right), 2.06(\mathrm{~s}, 3 \mathrm{H}), 1.76-1.51(\mathrm{~m}, 4 \mathrm{H}), 1.43-1.26(\mathrm{~m}, 2 \mathrm{H})$. ${ }^{13} \mathrm{C}$ NMR: $202.3(\mathrm{C}), 170.3(\mathrm{C}), 136.3(\mathrm{CH}), 116.8\left(\mathrm{CH}_{2}\right), 74.4(\mathrm{CH}), 43.6\left(\mathrm{CH}_{2}\right), 33.8$ $\left(\mathrm{CH}_{2}\right), 24.5\left(\mathrm{CH}_{2}\right), 21.7\left(\mathrm{CH}_{2}\right), 21.1\left(\mathrm{CH}_{3}\right)$. HRMS (ESI): calcd for $\mathrm{C}_{10} \mathrm{H}_{16} \mathrm{O}_{3} \mathrm{Na}$ $[\mathrm{M}+\mathrm{Na}]^{+}:$207.0992, found: 207.0989.

\section{5. $N$-(2-(1,3-dioxolan-2-yl)ethyl)-4-methylbenzenesulfonamide (21)}

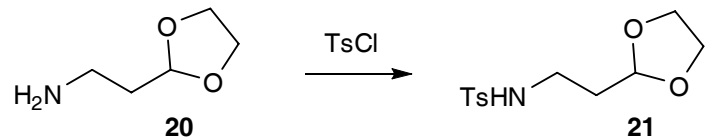

A solution of tosyl chloride $(822 \mathrm{mg} ; 4.31 \mathrm{mmol})$ in a minimum amount of dichloromethane was added to a cold $\left(0^{\circ} \mathrm{C}\right)$ solution of 2-(1,3-dioxolan-2-yl)ethanamine 20 (504.1 mg; $4.3 \mathrm{mmol}), \mathrm{Et}_{3} \mathrm{~N}(0.61 \mathrm{~mL} ; 4.385 \mathrm{mmol})$ and DMAP (5.3 mg; $\left.43 \mu \mathrm{mol}\right)$ in dichloromethane, with stirring, under an argon atmosphere. After $30 \mathrm{~min}$. at $0{ }^{\circ} \mathrm{C}$, stirring was continued at r. t. for $2 \mathrm{~h}$. Reaction mixture was diluted with dichloromethane ( 80 $\mathrm{mL})$, the extract is washed with sat. aq. $\mathrm{NaHCO}_{3}(50 \mathrm{~mL})$ and brine, dried over anh. $\mathrm{MgSO}_{4}$ and concentrated under reduced pressure. Purification of the residue by dry-flash chromatography (eluent: 33\% EtOAc in petroleum-ether) afforded $993.1 \mathrm{mg}(85 \%)$ of the title compound 21, as white crystals, m. p. $63{ }^{\circ} \mathrm{C}$. Spectral data for 21: $\mathrm{IR}_{\mathrm{KBr}}: 3270,2962$, 2896,1324, 1158, 1033, 670. ${ }^{1} \mathrm{H}$ NMR: $7.75(\mathrm{~d}, J=8.1,2 \mathrm{H}), 7.31(\mathrm{~d}, J=8.4,2 \mathrm{H}), 5.31$ $(\mathrm{t}, J=5.8,1 \mathrm{H}), 4.83(\mathrm{t}, J=4.2,1 \mathrm{H}), 3.93-3.75(\mathrm{~m}, 4 \mathrm{H}) 3.14-3.05(\mathrm{~m}, 2 \mathrm{H}), 2.42(\mathrm{~s}, 3 \mathrm{H})$, 1.87-1.78 (m, 2H). ${ }^{13} \mathrm{C}$ NMR: $143.2(\mathrm{C}), 136.8(\mathrm{C}), 129.6(\mathrm{CH}), 127.0(\mathrm{CH}), 103.1(\mathrm{CH})$, $64.8\left(\mathrm{CH}_{2}\right), 38.2\left(\mathrm{CH}_{2}\right), 32.0\left(\mathrm{CH}_{2}\right), 21.3\left(\mathrm{CH}_{3}\right)$. HRMS (ESI): calcd. for $\mathrm{C}_{12} \mathrm{H}_{18} \mathrm{NO}_{4} \mathrm{~S}$ $[\mathrm{M}+\mathrm{H}]^{+}: 272.0957$, found: 272.0957 . 


\section{6. (E)- $N$-(2-(1,3-dioxolan-2-yl)ethyl)- $N$-(4-bromobut-2-enyl)-4- methylbenzenesulfonamide (22)}<smiles>N/C=C/CBr</smiles>

A solution of sodium dimsyl anion, prepared from $\mathrm{NaH}(5.95 \mathrm{mg} ; 0.248 \mathrm{mmol})$ and DMSO $(0.5 \mathrm{~mL})$ was added to a solution of sulfonamide $21(56.2 \mathrm{mg} ; 0.207 \mathrm{mmol})$ in DMSO $(0.5 \mathrm{~mL})$ and the reaction mixture is stirred under an argon atmosphere for 30 min. This solution is added dropwise to a solution of $(E)$-1,4-dibromobut-2-ene (61 $\mathrm{mg}$; $0.285 \mathrm{mmol})$ in DMSO $(1 \mathrm{~mL})$. After stirring for $15 \mathrm{~min}$. at $\mathrm{r}$. t., the reaction mixture was diluted with brine and extracted with diethyl ether $(3 \times 50 \mathrm{~mL})$. The organic extract was dried over anh. $\mathrm{MgSO}_{4}$ and concentrated under reduced pressure. Purification by dryflash chromatography (eluent: 33\% EtOAc in petroleum-ether) afforded $29.7 \mathrm{mg}$ (35\%) of the title compound 22 (colorless, viscous oil), followwed by $13.3 \mathrm{mg}$ of the starting sulfonamide 21 (the yield of $\mathbf{2 2}$ based on the recovered 21 is $46 \%$ ). Spectral data for 22 : $\mathrm{IR}_{\text {film: }}$ : 2957, 2884, 1338, 1158, 1022, 899, 549. ${ }^{1} \mathrm{H}$ NMR: 7.69 (d, $\left.J=8.5,2 \mathrm{H}\right), 7.30$ (d, $J$ $=7.9,2 \mathrm{H}), 5.91-5.55(\mathrm{~m}, 2 \mathrm{H}), 4.85(\mathrm{t}, J=4.6,1 \mathrm{H}), 3.97-3.77(\mathrm{~m}, 8 \mathrm{H}), 3.30-3.22(\mathrm{~m}$, 2H), $2.42(\mathrm{~s}, 3 \mathrm{H}), 1.94-1.84(\mathrm{~m}, 2 \mathrm{H}) .{ }^{13} \mathrm{C}$ NMR: $143.3(\mathrm{C}), 136.8(\mathrm{C}), 130.3(\mathrm{CH}), 130.0$ $(\mathrm{CH}), 129.7(\mathrm{CH}), 127.2(\mathrm{CH}), 102.1(\mathrm{CH}), 64.9\left(\mathrm{CH}_{2}\right), 49.1\left(\mathrm{CH}_{2}\right), 42.7\left(\mathrm{CH}_{2}\right), 32.7$ $\left(\mathrm{CH}_{2}\right), 31.3\left(\mathrm{CH}_{2}\right), 21.4\left(\mathrm{CH}_{3}\right)$. HRMS (ESI): calcd. for $\mathrm{C}_{16} \mathrm{H}_{23} \mathrm{BrNO}_{4} \mathrm{~S}[\mathrm{M}+\mathrm{H}]^{+}$: 404.0531, found: 404.0520 .

\section{7. (E)- $N$-(4-bromobut-2-enyl)-4-methyl- $N$-(3-oxopropyl)benzenesulfonamide (8)}

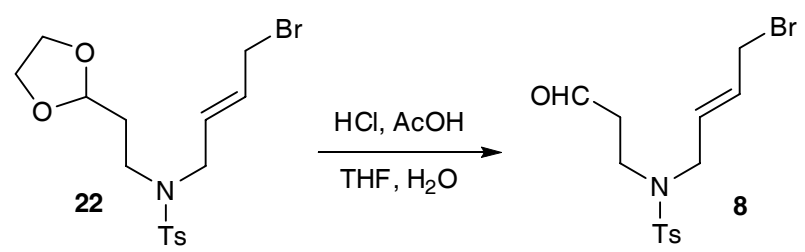

Acetic acid $(0.75 \mathrm{~mL})$, water $(0.75 \mathrm{~mL})$ and $6 \mathrm{M}$ hydrochloric acid $(0.9 \mathrm{~mL})$ were added to a solution of acetal $22(35.4 \mathrm{mg} ; 88 \mu \mathrm{mol})$ in THF $(0.75 \mathrm{~mL})$, and the mixture was stirred at r. t. After $2 \mathrm{~h}$, the reaction was quenched by addition of sat. aq. $\mathrm{NaHCO}_{3}(15$ $\mathrm{mL})$ and extracted with EtOAc $(15 \mathrm{~mL}+10 \mathrm{~mL})$. The organic extract was dried over anh. $\mathrm{MgSO}_{4}$ and concentrated under reduced pressure. Purification of the residue by column chromatography (eluent: 14\% EtOAc in toluene) afforded $28.6 \mathrm{mg}(91 \%)$ of the title compound 8, as a pale-yellow liquid. Spectral data for 8: $\mathrm{IR}_{\text {film: }}$ : 3424, 2922, 2851, 2733 , 1722, 1450, 1338, 1157, 915. ${ }^{1} \mathrm{H}$ NMR: $9.75(\mathrm{~s}, 1 \mathrm{H}), 7.71-7.67(\mathrm{~m}, 2 \mathrm{H}), 7.37-7.31(\mathrm{~m}$, $2 \mathrm{H}), 5.69(\mathrm{~m}, 2 \mathrm{H}), 4.00-3.86(\mathrm{~m}, 2 \mathrm{H}) 3.80(\mathrm{~d}, J=5.8), 3.41(\mathrm{t}, J=7.0,2 \mathrm{H}), 2.82(\mathrm{t}, J=$ 7.0, 2H), $2.44(\mathrm{~s}, 3 \mathrm{H}){ }^{13} \mathrm{C}$ NMR: $200.2(\mathrm{CH}), 143.7(\mathrm{C}), 136.0(\mathrm{C}), 130.3(\mathrm{CH}), 129.9$ $(\mathrm{CH}), 129.3(\mathrm{CH}), 127.2(\mathrm{CH}), 50.1\left(\mathrm{CH}_{2}\right), 43.8\left(\mathrm{CH}_{2}\right), 43.7\left(\mathrm{CH}_{2}\right), 41.2\left(\mathrm{CH}_{2}\right), 21.5$ $\left(\mathrm{CH}_{3}\right)$. HRMS (ESI): calcd. for $\mathrm{C}_{14} \mathrm{H}_{19} \mathrm{BrNO}_{3} \mathrm{~S}[\mathrm{M}+\mathrm{H}]^{+}: 360.0269$, found: 360.0285 . 


\section{8. (E)-ethyl 9,9-dimethoxynon-2-enoate (24)}

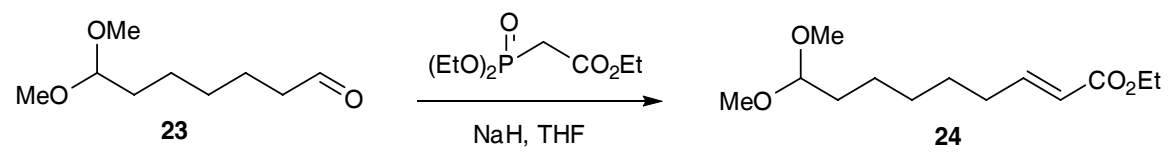

Ethyl 2-(diethoxyphosphoryl)acetate $(5.4 \mathrm{~g} ; 24.1 \mathrm{mmol})$ was added dropwise to a cold (0 $\left.{ }^{\circ} \mathrm{C}\right)$ suspension of sodium hydride $(636 \mathrm{mg} ; 26.5 \mathrm{mmol})$ in THF $(35 \mathrm{~mL})$, with stirring under an argon atmosphere. After 30 min., a solution of aldehyde $\mathbf{2 3}^{7}$ (4.2 g; $24.1 \mathrm{mmol}$ ) in THF $(5 \mathrm{~mL})$ was added dropwise and the reaction mixture was stirred at $r$. $r$. for $2 \mathrm{~h}$. The mixture was diluted with water $(50 \mathrm{~mL})$ and exctracted with dichloromethane $(2 \times 30$ $\mathrm{mL})$. The organic extract was dried over anh. $\mathrm{MgSO}_{4}$ and concentrated under reduced pressure. Purification by dry-flash chromatography (eluent: $10 \%$ ethyl acetate in petroleum-ether) afforded $5 \mathrm{~g}(85 \%)$ of the title compound 24 as a colorless liquid.

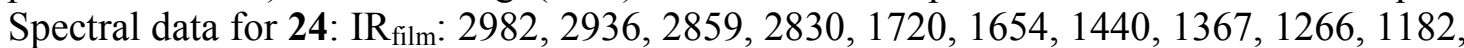
1127, 1051, 985. ${ }^{1} \mathrm{H}$ NMR: 7.03-6.88 (m, H), 5.86-5.76 (m, H), $4.35(\mathrm{t}, J=5.2, \mathrm{H}), 4.18$ $(\mathrm{q}, J=7.0,2 \mathrm{H}), 3.31(\mathrm{~s}, 6 \mathrm{H}), 2.25(\mathrm{~m}, 2 \mathrm{H}), 1.64-1.25(\mathrm{~m}, 8 \mathrm{H}), 1.28(\mathrm{t}, J=7.0,3 \mathrm{H}) .{ }^{13} \mathrm{C}$ NMR: $149.2(\mathrm{CH}), 121.3(\mathrm{CH}), 104.4(\mathrm{CH}), 60.1\left(\mathrm{CH}_{2}\right), 52.6(\mathrm{CH}), 32.3\left(\mathrm{CH}_{2}\right), 32.0$ $\left(\mathrm{CH}_{2}\right), 28.9\left(\mathrm{CH}_{2}\right), 27.9\left(\mathrm{CH}_{2}\right), 24.3\left(\mathrm{CH}_{2}\right), 14.2\left(\mathrm{CH}_{3}\right)$. HRMS (ESI): calcd for $\mathrm{C}_{13} \mathrm{H}_{24} \mathrm{O}_{4} \mathrm{Na}[\mathrm{M}+\mathrm{Na}]^{+}: 267.1567$, found: 267.1585 .

\section{9. (E)-9,9-dimethoxynon-2-en-1-ol (25)}

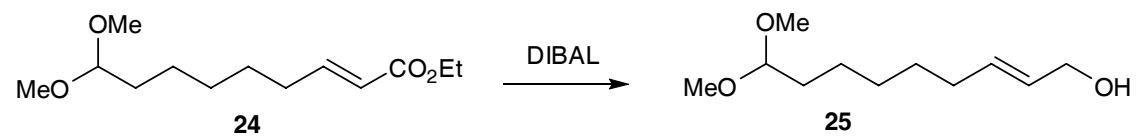

DIBAL $(2.7 \mathrm{~mL}$ of $1.5 \mathrm{M}$ solution in toluene; $4.08 \mathrm{mmol})$ was added to a cold $\left(-78{ }^{\circ} \mathrm{C}\right)$ solution of ester $24(0.5 \mathrm{~g} ; 2.04 \mathrm{mmol})$ in dichloromethane $(11 \mathrm{~mL})$. After $20 \mathrm{~min}$., the reaction mixture was quenched with isopropanol and water and extracted with EtOAc. The organic extract was dried over anh. $\mathrm{MgSO}_{4}$, concentrated under reduced pressure and purified by dry-flash chromatography (30\% EtOAc in petroleum-ether) to give $0.39 \mathrm{~g}$ (95\%) of the title compound 25 as a colorless oil. Spectral data for 25: IR film: 3411, 2929, 2856, 1669, 1462, 1385, 1157, 1128, 1054, 1007, 970. ${ }^{1} \mathrm{H}$ NMR: 5.76-5.55 (m, 2H), 4.36 $(\mathrm{t}, J=10.6,1 \mathrm{H}), 4.08(\mathrm{~d}, J=4.6,2 \mathrm{H}), 3.31(\mathrm{~s}, 6 \mathrm{H}), 2.06(\mathrm{~m}, 3 \mathrm{H}), 1.64-1.54(\mathrm{~m}, 2 \mathrm{H})$, 1.46-1.29 (m, 5H). ${ }^{13} \mathrm{C}$ NMR: $133.1(\mathrm{CH}), 130.0(\mathrm{CH}), 104.4(\mathrm{CH}), 63.6\left(\mathrm{CH}_{2}\right), 52.5$ $(\mathrm{CH}), 32.3\left(\mathrm{CH}_{2}\right), 33.20\left(\mathrm{CH}_{2}\right), 28.9\left(\mathrm{CH}_{2}\right), 28.8\left(\mathrm{CH}_{2}\right), 24.3\left(\mathrm{CH}_{2}\right)$. HRMS (ESI): calcd. for $\mathrm{C}_{11} \mathrm{H}_{22} \mathrm{O}_{3} \mathrm{Na}[\mathrm{M}+\mathrm{Na}]^{+}: 225.1461$, found: 225.1456 . 


\subsection{0. (E)-9-bromonon-7-enal (9)}
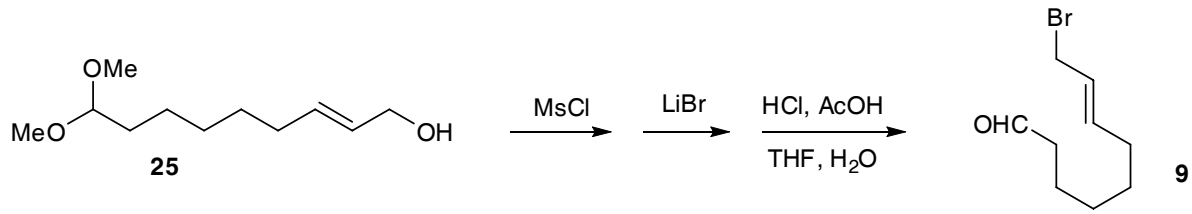

Mesyl chloride $(220 \mathrm{mg} ; 157 \mu \mathrm{L} ; 1.92 \mathrm{mmol})$ was added dropwise to a cold $\left(-15{ }^{\circ} \mathrm{C}\right)$ solution of triethylamine (224 mg; $285 \mu \mathrm{L} ; 2.22 \mathrm{mmol})$ and alcohol 25 (300 mg; 1.48 $\mathrm{mmol})$ in dichloromethane $(2 \mathrm{~mL})$, with stirring, under an argon atmosphere. Upon completion, the reaction mixture was diluted with diethyl ether $(10 \mathrm{~mL})$ and saturated aq. $\mathrm{NaHCO}_{3}(10 \mathrm{~mL})$, and the mixture was stirred for $20 \mathrm{~min}$. The organic layer was separated, and the aqueous layer was extracted with dichloromethane $(2 \times 120 \mathrm{~mL})$. The combined organic extract was washed with water, dried over anh. $\mathrm{MgSO}_{4}$ and concentrated under reduced pressure, to give $406 \mathrm{mg}(98 \%)$ of the crude mesylate, which was used in the next step without further purification.

A solution of $\operatorname{LiBr}(1.28 \mathrm{~g} ; 14.8 \mathrm{mmol})$ in THF $(6 \mathrm{~mL})$ was added to a cold $\left(0{ }^{\circ} \mathrm{C}\right)$ solution of the mesylate (from the previous step; $406 \mathrm{mg} ; 1.44 \mathrm{mmol}$ ) in dichloromethane $(4.5 \mathrm{~mL})$. The reaction mixture was stirred for $20 \mathrm{~min}$. at r. t., followed by dilution with water and extraction with dichloromethane $(2 \times 20 \mathrm{~mL})$. The organic extract was washed with water, dried over anh. $\mathrm{MgSO}_{4}$ and concentrated under reduced pressure. The crude product was purified by dry-flash chromatography (eluent: $10 \%$ ethyl acetate in petroleum-ether), to give $278 \mathrm{mg}(78 \%)$ of the acetal which was immediately used in the next step.

A solution of the acetal (from the previous step; $278 \mathrm{mg} ; 1.04 \mathrm{mmol}$ ) in a mixture of solvents $\left(\mathrm{THF} / \mathrm{H}_{2} \mathrm{O} / \mathrm{AcOH}=1 / 1 / 1\right.$, total volume $\left.6 \mathrm{~mL}\right)$ was stirred at $\mathrm{r}$. $\mathrm{t}$. for $30 \mathrm{~min}$. Upon completion, the reaction mixture was extracted with dichloromethane $(2 \times 25 \mathrm{~mL})$, and the extract was washed with sat. aq. $\mathrm{NaHCO}_{3}$ and water, dried over anh. $\mathrm{MgSO}_{4}$ and concentrated under reduced pressure. Purification of the crude material by dry-flash chromatography (eluent: 10\% EtOAc in petroleum-ether) afforded $184 \mathrm{mg}(80 \%)$ of the title compound 9, as a colorless oil. Physical data for 9: $\mathrm{IR}_{\text {film: }}$ : 2931, 2856, 2720, 1724, 1659, 1461, 1436, 1390, 1204, 966. ${ }^{1} \mathrm{H}$ NMR: $9.77(\mathrm{t}, J=1.8,1 \mathrm{H}), 5.84-5.60(\mathrm{~m}, 2 \mathrm{H})$, $3.94(\mathrm{~d}, J=2.6,2 \mathrm{H}), 2.43\left(\mathrm{dt}, J^{l}=5.4, J^{2}=1.8,2 \mathrm{H}\right), 2.13-2.03(\mathrm{~m}, 2 \mathrm{H}), 1.70-1.56(\mathrm{~m}$, 2H), 1.51-1.26 (m, 4H). ${ }^{13} \mathrm{C}$ NMR: $202.7(\mathrm{C}), 136.2(\mathrm{CH}), 126.6(\mathrm{CH}), 43.7\left(\mathrm{CH}_{2}\right), 33.4$ $\left(\mathrm{CH}_{2}\right), 31.7\left(\mathrm{CH}_{2}\right), 28.4\left(\mathrm{CH}_{2}\right), 21.8\left(\mathrm{CH}_{2}\right)$.

\subsection{1. (E)-9-oxonon-2-enyl acetate (10)}

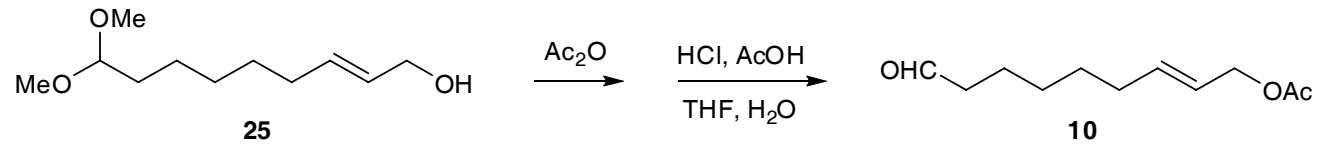

Acetic anhydride $(117 \mathrm{mg} ; 108 \mu \mathrm{L} ; 1.15 \mathrm{mmol})$ was added dropwise to a cold $\left(0{ }^{\circ} \mathrm{C}\right)$ solution of alcohol 25 (155 mg; $0.766 \mathrm{mmol})$, triethylamine $(155 \mathrm{mg} ; 210 \mu \mathrm{L} ; 1.53$ mmol) and DMAP (cat. amount) in dichloromethane $(2 \mathrm{~mL})$. After $10 \mathrm{~min}$. the reaction 
mixture was diluted with dichloromethane, washed with water, sat. aq. $\mathrm{NaHCO}_{3}$ and water, dried over anh. $\mathrm{MgSO}_{4}$ and concentrated under reduced pressure. Purification by dry-flash chromatography (eluent: $10 \%$ ethyl acetate in petroleum-ether) afforded $159 \mathrm{mg}$ $(85 \%)$ of the acetate, which was immediately used in the next step.

A solution of the acetate (from the previous step; $159 \mathrm{mg} ; 1.19 \mathrm{mmol}$ ), THF $(1 \mathrm{~mL}), \mathrm{H}_{2} \mathrm{O}$ $(1 \mathrm{~mL}), \mathrm{AcOH}(1 \mathrm{~mL})$ and one drop of $18 \% \mathrm{HCl}$ was stirred at $\mathrm{r}$. t. for $1 \mathrm{~h}$. The reaction mixture was extracted with dichloromethane, washed with sat. aq. $\mathrm{NaHCO}_{3}$ and water, dried over anh. $\mathrm{MgSO}_{4}$ and concentrated under reduced pressure. Purification by dryflash chromatography (eluent: 10\% ethyl acetate in petroleum-ether) afforded $105 \mathrm{mg}$ (81\%) of the title compound 10, as a colorless oil. Spectral data for 10: $\operatorname{IR}_{\text {film: }}$ : 2934, 2858, 2722, 1739, 1635, 1363, 1232, 1025, 969, 733. ${ }^{1} \mathrm{H}$ NMR: $9.76(\mathrm{t}, J=2, \mathrm{H}), 5.83-5.69$ (m, H), 5.63-5.48 (m, H), $4.50\left(\mathrm{dd}, J^{l}=6.2, J^{2}=0.8,2 \mathrm{H}\right), 2.40\left(\mathrm{dt}, J^{l}=7, J^{2}=1.6,2 \mathrm{H}\right)$, 2.17-2.02 (m, 2H). $2.05(\mathrm{~s}, 3 \mathrm{H}), 1.73-1.56(\mathrm{~m}, 2 \mathrm{H}), 1.50-1.25(4 \mathrm{H}) .{ }^{13} \mathrm{C}$ NMR: 202.4 $(\mathrm{CH}), 170.6(\mathrm{C}), 135.8(\mathrm{CH}), 123.9(\mathrm{CH}), 64.9\left(\mathrm{CH}_{2}\right), 43.5\left(\mathrm{CH}_{2}\right), 31.7\left(\mathrm{CH}_{2}\right), 28.3$ $\left(\mathrm{CH}_{2}\right), 21.6\left(\mathrm{CH}_{2}\right), 20.7\left(\mathrm{CH}_{3}\right)$. HRMS (ESI): calcd. for $\mathrm{C}_{11} \mathrm{H}_{18} \mathrm{O}_{3} \mathrm{Na}[\mathrm{M}+\mathrm{Na}]^{+}$: 221.1148, found: 221.1152 .

\section{Organo-catalyzed cyclizations of $\pi$-allylpalladium intermediates}

\subsection{Diastereoselective cyclizations}

2.1.1. General procedure for the cyclization: trans-2-vinylcyclopentanecarbaldehyde (12) (Method A; due to high volatility of 12, it was in situ reduced and isolated as the corresponding alcohol)

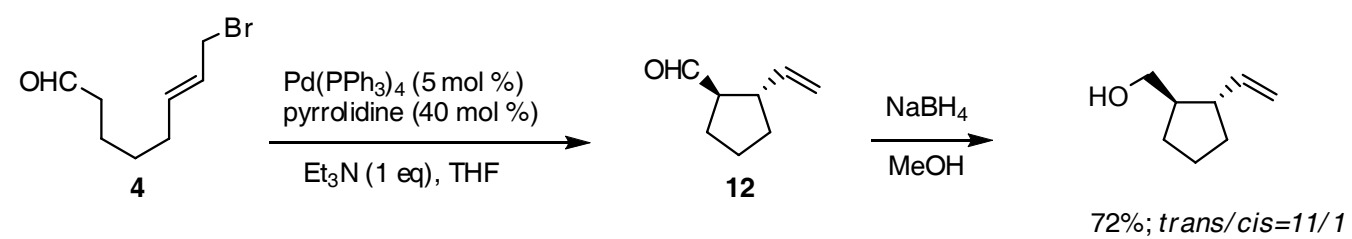

A solution of $\mathrm{Pd}\left(\mathrm{PPh}_{3}\right)_{4}(8.9 \mathrm{mg} ; 7.8 \mu \mathrm{mol} ; 5 \mathrm{~mol} \%)$, aldehyde 4 (32 mg; $\left.0.156 \mathrm{mmol}\right)$, pyrrolidine $(4.4 \mathrm{mg} ; 5.16 \mu \mathrm{L} ; 6.24 \mu \mathrm{mol} ; 40 \mathrm{~mol} \%)^{8}$ and $\mathrm{Et}_{3} \mathrm{~N}(15.7 \mathrm{mg} ; 21.6 \mu \mathrm{L} ; 0.156$ mmol) was stirred at $r$. t., under an argon atmosphere. The reaction was monitored by TLC $(20 \%$ EtOAc in petroleum-ether). After $30 \mathrm{~min}$., methanol $(2 \mathrm{~mL})$ was added, the reaction mixture was cooled $\left(0{ }^{\circ} \mathrm{C}\right)$ and $\mathrm{NaBH}_{4}(58 \mathrm{mg} ; 10 \mathrm{eq})$ was added in several portions. The reaction mixture was diluted with EtOAc $(60 \mathrm{~mL})$, washed with water, dried over anh. $\mathrm{MgSO}_{4}$ and concentrated under reduced pressure. Purification of the residue by dry-flash chromatography (eluent: 20\% EtOAc in hexanes) afforded $14.1 \mathrm{mg}$ (72\%) of 2-hydroxymethyl-1-vinylcyclopentane, as a colorless oil. The product was obtained as a mixture of isomers in a ratio trans: $c i s=11: 1$, as determined by GC. ${ }^{1} \mathrm{H}$ and ${ }^{13} \mathrm{C}$ NMR spectra are identical with those previously reported in the literature and show that the major isomer has trans-configuration. ${ }^{9}$ Provided here are the spectral data that have not been previously reported: $\mathrm{IR}_{\text {film: }}$ 3338, 3077, 2951, 2870, 1638, 14501421 , 
1319, 1020, 994, 908, 803. HRMS (ESI): calcd. for $\mathrm{C}_{8} \mathrm{H}_{13} \mathrm{O}[\mathrm{M}+\mathrm{H}]^{+}:$127.1117, found: 127.1115.

2.1.2. General procedure for the cyclization: trans-2-vinylcyclopentanecarbaldehyde (12) (Method B; due to high volatility of 12, it was in situ reduced and isolated as the corresponding alcohol) ${ }^{10}$
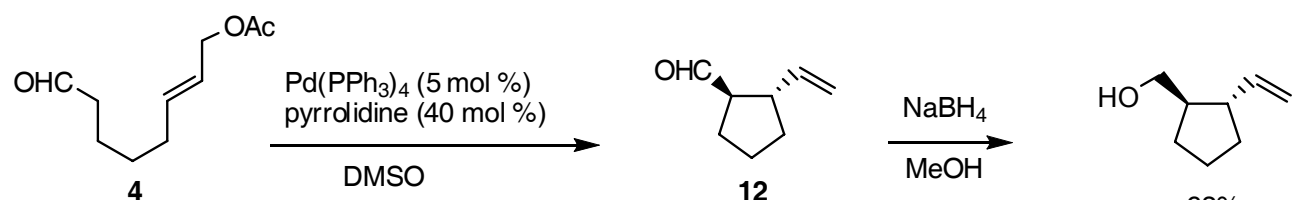

$63 \%$

A mixture of $\mathrm{Pd}(\mathrm{OAc})_{2}(1.82 \mathrm{mg} ; 8.1 \mu \mathrm{mol} ; 5 \mathrm{~mol} \%), \mathrm{PPh}_{3}(8.54 \mathrm{mg} ; 32.5 \mu \mathrm{mol})$ and DMSO $(0.5 \mathrm{~mL})$ was stirred at r. t., under an argon atmosphere, for $10 \mathrm{~min}$., while a yellow precipitate formed. To this supension was added a solution of aldehyde 5 (30 $\mathrm{mg}$; $0.162 \mathrm{mmol})$ in DMSO $(0.5 \mathrm{~mL})$ and the reaction mixture was stirred for an additional 10 min., when pyrrolidine $(4.6 \mathrm{mg} ; 5.4 \mu \mathrm{L} ; 0.65 \mathrm{mmol} ; 40 \mathrm{~mol} \%)$ was added. In situ reduction with $\mathrm{NaBH}_{4}$ and work-up as described in 2.1.1. afforded $13 \mathrm{mg}(63 \%)$ of trans(2-vinylcyclopentyl)methanol.

\subsubsection{Trans-2-vinylcyclopentanecarbaldehyde (12) from the regioisomeric precursor} (6).<smiles>C=CC1CCCC(C=O)C1=O</smiles>

6

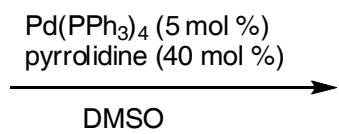

DMSO

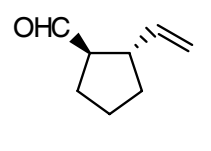

$12 ; 53 \%$

According to the General procedure - Method B. Yield: 53\%; diastereoselectivity: 4trans:4-cis $=2: 1$, as determined by integrating peaks at $9.68 \mathrm{ppm}$ and $9.61 \mathrm{ppm}$ in the ${ }^{1} \mathrm{H}$ NMR spectrum, corresponding to the aldehyde protons of the 4-cis and 4-trans stereoisomers, respectively.

\subsubsection{Diethyl trans-3-formyl-4-vinylcyclopentane-1,1-dicarboxylate (13)}<smiles>CCOC(OCC)C(C/C=C/CBr)(CCC=O)OCC</smiles>

7

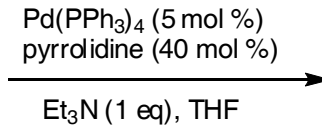

$\mathrm{Et}_{3} \mathrm{~N}(1 \mathrm{eq}), \mathrm{THF}$<smiles>C=C[C@H]1C[C@](C=O)(C(OCC)OCC)C[C@H]1C=O</smiles>

13; $75 \%$

According to the General procedure - Method A. Starting from aldehyde 7 (57 mg; 0.163 $\mathrm{mmol}), \mathrm{Pd}\left(\mathrm{PPh}_{3}\right)_{4}(9.4 \mathrm{mg} ; 8.16 \mu \mathrm{mol} ; 5 \mathrm{~mol} \%)$, pyrrolidine $(11.6 \mathrm{mg} ; 13.6 \mu \mathrm{L} ; 0.163$ 
mmol) and THF $(0.75 \mathrm{~mL}), 31.8 \mathrm{mg}(75 \%)$ of the title compound 13 was obtained as a colorless oil. The ratio of diastereoisomers determined by GC was 13-trans:13-cis=13:1. Spectral data for 13-trans: IR film: 2982, 2938, 2725, 1728, 1642, 1446, 1390, 1367, 1258, 1181, 1096, 1023, 921, 860. ${ }^{1} \mathrm{H}$ NMR: $9.62(\mathrm{~d}, J=2.2, \mathrm{H}), 5.86-5.69(\mathrm{~m}, \mathrm{H}), 5.21-5.04$ $(\mathrm{m}, 2 \mathrm{H}), 4,19(\mathrm{q}, J=6.6,4 \mathrm{H}), 2.94-2.80(\mathrm{~m}, \mathrm{H}), 2.76-2.41(\mathrm{~m}, 4 \mathrm{H}), 2.25-2.02(\mathrm{~m}, \mathrm{H})$, $1.26(\mathrm{t}, J=6.6,6 \mathrm{H}) .{ }^{13} \mathrm{C}$ NMR: $201.6(\mathrm{C}), 171.5(\mathrm{C}), 138.2(\mathrm{CH}), 116.2\left(\mathrm{CH}_{2}\right), 61.7$ $\left(\mathrm{CH}_{2}\right), 59.06(\mathrm{C}), 56.2(\mathrm{CH}), 44.7(\mathrm{CH}), 40.1\left(\mathrm{CH}_{2}\right), 33.7\left(\mathrm{CH}_{2}\right), 13.90\left(\mathrm{CH}_{3}\right)$.

\subsubsection{Trans-1-tosyl-4-vinylpyrrolidine-3-carbaldehyde (14)}

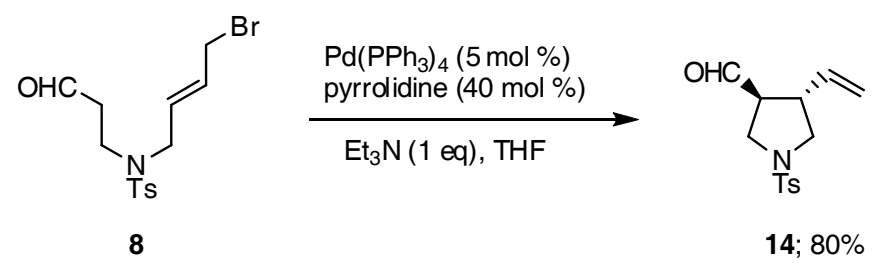

According to the General procedure - Method A. Starting from aldehyde $8(57.1 \mathrm{mg}$; $0.158 \mathrm{mmol}), \mathrm{Pd}\left(\mathrm{PPh}_{3}\right)_{4}(12.8 \mathrm{mg} ; 11 \mu \mathrm{mol})$, pyrrolidine $(2.6 \mu \mathrm{L} ; 0.16 \mathrm{mmol}), \mathrm{Et}_{3} \mathrm{~N}(22.5$ $\mathrm{mL} ; 0.16 \mu \mathrm{mol})$ and THF $(2.15 \mathrm{~mL})$; the reaction required $4 \mathrm{~h}$ at $\mathrm{r}$. $\mathrm{t}$. for completion. Upon completion the reaction mixture was concentrated under reduced pressure with $\mathrm{SiO}_{2}(400 \mathrm{mg}$ ) and the residue was purified by column chromatography (eluent: $33 \%$ EtOAc in toluene), to give $35.6 \mathrm{mg}(80 \%)$ of the title compound $\mathbf{1 4}$ as a yellow oil. Spectral data for 14: IR: 3433, 2923, 2886, 1725, 1343, 1162, 1016, 664. ${ }^{1} \mathrm{H}$ NMR: 9.53 $(\mathrm{d}, J=1.6,1 \mathrm{H}), 7.76-7.70(\mathrm{~m}, 2 \mathrm{H}), 7.40-7.33(\mathrm{~m}, 2 \mathrm{H}), 5.74-5.57(\mathrm{~m}, 1 \mathrm{H}), 5.16-5.07(\mathrm{~m}$, 2H), 3.63-3.40 (m, 3H), 3.16-2.87 (m, 2H), 2.82-2.69 (m, 1H), $2.45(\mathrm{~s}, 3 \mathrm{H}){ }^{13} \mathrm{C}$ NMR: $198.7(\mathrm{CH}), 144.0(\mathrm{C}), 135.4(\mathrm{CH}), 129.8(\mathrm{CH}), 127.6(\mathrm{CH}), 118.0\left(\mathrm{CH}_{2}\right), 55.2(\mathrm{CH})$, $52.3\left(\mathrm{CH}_{2}\right), 46.7\left(\mathrm{CH}_{2}\right), 43.6(\mathrm{CH}), 21.5\left(\mathrm{CH}_{3}\right)$; one peak corresponding to a quaternary carbon atom could not be observed under the recording conditions. HRMS (ESI): calcd. for $\mathrm{C}_{14} \mathrm{H}_{17} \mathrm{NO}_{3} \mathrm{~S}[\mathrm{M}]^{+}:$279.0929, found: 279.0927.

2.1.6. Trans-2-vinylcyclohexanecarbaldehyde (15) (from 9, isolated as the corresponding alcohol, after in situ reduction with $\mathrm{NaBH}_{4}$ )
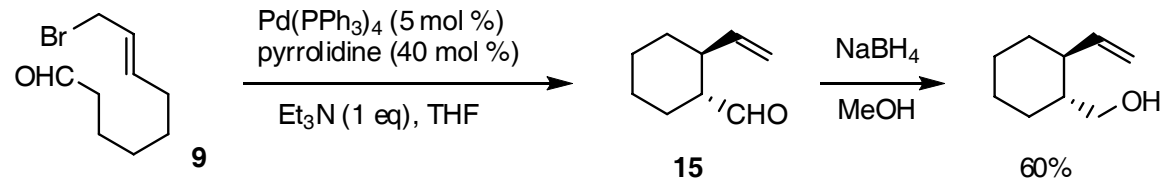

According to the General procedure - Method A. Starting from aldehyde 9 (26 mg; 0.118 $\mathrm{mmol}), \mathrm{Pd}\left(\mathrm{PPh}_{3}\right)_{4}(6.8 \mathrm{mg} ; 5.93 \mu \mathrm{mol} ; 5 \mathrm{~mol} \%)$, pyrrolidine $(8.4 \mathrm{mg} ; 9.8 \mu \mathrm{L} ; 0.118$ $\mathrm{mmol})$ and THF $(0.5 \mathrm{~mL})$, the reaction was complete in $30 \mathrm{~min}$. After completion, methanol $(2 \mathrm{~mL})$ was added to the reaction mixture, followed by $\mathrm{NaBH}_{4}(44 \mathrm{mg} ; 10 \mathrm{eq})$. Work-up as described before afforded $10 \mathrm{mg}(60 \%)$ of (trans-2vinylcyclohexyl)methanol, as a colorless oil. Spectral data for (trans-2- 


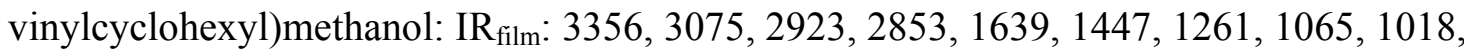
995, 910. ${ }^{1} \mathrm{H}$ NMR: $5.73\left(\mathrm{ddd}, J^{l}=17.3, J^{2}=10.1, J^{3}=8.1, \mathrm{H}\right), 5.09-4.94(\mathrm{~m}, 2 \mathrm{H}), 3.62$ $\left(\mathrm{dd}, J^{l}=10.9, J^{2}=4.6, \mathrm{H}\right), 3.44\left(\mathrm{dd}, J^{l}=10.9, J^{2}=5.6, \mathrm{H}\right), 1.94-1.09(\mathrm{~m}, 10 \mathrm{H}) .{ }^{13} \mathrm{C}$ NMR: $143.8(\mathrm{CH}), 114.1\left(\mathrm{CH}_{2}\right), 67.2\left(\mathrm{CH}_{2}\right), 46.0(\mathrm{CH}), 44.3(\mathrm{CH}), 33.4\left(\mathrm{CH}_{2}\right), 29.1$ $\left(\mathrm{CH}_{2}\right), 25.8\left(\mathrm{CH}_{2}\right), 25.7\left(\mathrm{CH}_{2}\right)$. HRMS (ESI): calcd. for $\mathrm{C}_{9} \mathrm{H}_{17} \mathrm{O}[\mathrm{M}+\mathrm{H}]^{+}:$141.1274, found: 141.1274 .

\subsubsection{Trans-2-vinylcyclohexanecarbaldehyde 15 (from 10)}

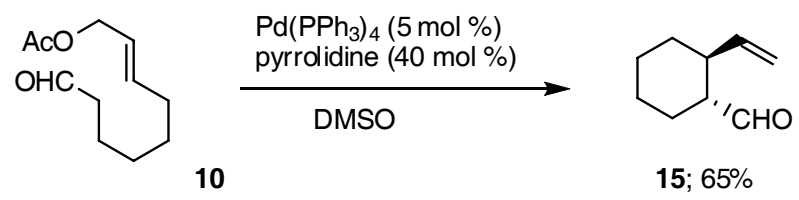

According to the General procedure - Method B. Starting from aldehyde 10 (30 mg; $0.151 \mathrm{mmol}), \mathrm{Pd}\left(\mathrm{PPh}_{3}\right)_{4}(8.7 \mathrm{mg} ; 7.57 \mu \mathrm{mol} ; 5 \mathrm{~mol} \%)$, pyrrolidine $(10.7 \mathrm{mg} ; 12.6 \mu \mathrm{L}$; $0.151 \mathrm{mmol})$ and DMSO $(0.75 \mathrm{~mL})$, the reaction was complete in $2 \mathrm{~h}$. Work-up as previously described, followed by purification by dry-flash chromatography (eluent: $5 \%$ EtOAc in hexanes) afforded $13.5 \mathrm{mg}(64.5 \%)$ of the title compound 15. Spectral data for

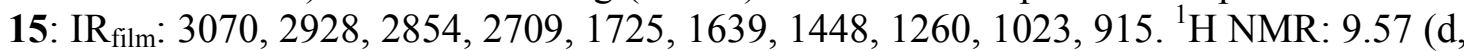
$J=3.2, \mathrm{H}), 5.81-5.62(\mathrm{~m}, \mathrm{H}), 5.15-4.93(\mathrm{~m}, 2 \mathrm{H}), 2.40-2.06(\mathrm{~m}, 2 \mathrm{H}), 1.82-1.74(\mathrm{~m}, 4 \mathrm{H})$, 1.47-1.24 (m, 4H). ${ }^{13} \mathrm{C}$ NMR: $205.1(\mathrm{C}), 141.2(\mathrm{CH}), 114.9\left(\mathrm{CH}_{2}\right), 54.3(\mathrm{CH}), 42.1(\mathrm{CH})$, $31.9\left(\mathrm{CH}_{2}\right), 25.7\left(\mathrm{CH}_{2}\right), 25.1\left(\mathrm{CH}_{2}\right), 24.5\left(\mathrm{CH}_{2}\right)$.

\subsection{Enantioselective cyclizations}

\subsection{1. (-)-Diethyl trans-3-formyl-4-vinylcyclopentane-1,1-dicarboxylate (-)-13}

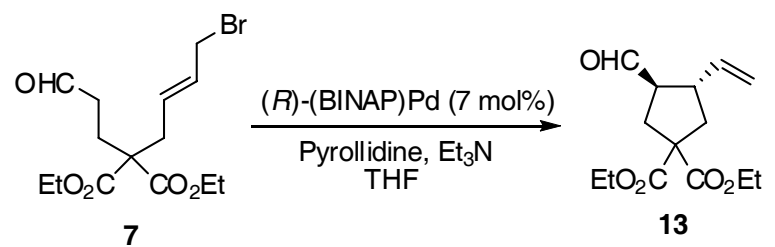

$0{ }^{\circ} \mathrm{C}, 2$ h: $40 \%, 37 \%$ ee $-20{ }^{\circ} \mathrm{C}, 4 \mathrm{~h}: 40 \%, 91 \%$ ee

A mixture of $\mathrm{Pd}(\mathrm{OAc})_{2}(2.69 \mathrm{mg} ; 12 \mu \mathrm{mol})$ and $(R)-(+)$-BINAP $(14.96 \mathrm{mg} ; 24 \mu \mathrm{mol})$ in THF $(1 \mathrm{~mL})$ was stirred for $10 \mathrm{~min}$. at $\mathrm{r}$. t. under an argon atmosphere. The reaction mixture was cooled to $-20{ }^{\circ} \mathrm{C}$, aldehyde $7(0.172 \mathrm{mmol})$ was added, followed by, after 10 min, pyrrolidine $(24.4 \mathrm{mg} ; 28.6 \mu \mathrm{L} ; 0.344 \mathrm{mmol})$ and triethylamine $(86.86 \mathrm{mg} ; 119 \mu \mathrm{L}$; $0.86 \mathrm{mmol})$. After the reaction was complete $(4 \mathrm{~h})$, it was diluted with dichloromethane, washed with water, dried over anhydrous $\mathrm{MgSO}_{4}$ and concentrated under reduced pressure. Purification by dry-flash chromatography $\left(\mathrm{SiO}_{2}\right.$, eluent: $10 \%$ ethyl acetate in toluene), afforded $18.5 \mathrm{mg}(40 \%)$ of the title compound 13 as a colorless oil. 13-trans:13cis $=6: 1$; 13-trans: $91 \%$ ee; 13-cis: $82 \%$ ee, as determined by a chiral GC analysis on 
HP-Chiral column. Physical data for 13-trans: IR film: 2982, 2938, 2725 1728, 1642, 1446, 1390, 1367, 1258, 1181, 1096, 1023, 921, 860. ${ }^{1} \mathrm{H}$ NMR: 9.62 (d, $\left.J=2.2 \mathrm{~Hz}, \mathrm{H}\right), 5.86-$ $5.69(\mathrm{~m}, \mathrm{H}), 5.21-5.04(\mathrm{~m}, 2 \mathrm{H}), 4.19(\mathrm{q}, J=6.6 \mathrm{~Hz}, 4 \mathrm{H}), 2.94-2.80(\mathrm{~m}, \mathrm{H}), 2.76-2.41(\mathrm{~m}$, $4 \mathrm{H}), 2.25-2.02(\mathrm{~m}, \mathrm{H}), 1.26(\mathrm{t}, J=6.6 \mathrm{~Hz}, 6 \mathrm{H}) .{ }^{13} \mathrm{C}$ NMR: $201.6(\mathrm{C}), 171.5(\mathrm{C}), 138.2$ $(\mathrm{CH}), 116.2\left(\mathrm{CH}_{2}\right), 61.7\left(\mathrm{CH}_{2}\right), 59.06(\mathrm{C}), 56.2(\mathrm{CH}), 44.7(\mathrm{CH}), 40.1\left(\mathrm{CH}_{2}\right), 33.7\left(\mathrm{CH}_{2}\right)$, $\left.13.90\left(\mathrm{CH}_{3}\right) .[\alpha]_{285}=-15.7(c), \mathrm{CHCl}_{3}\right)$. HRMS (ESI): under the standard recording conditions, the molecular ion could not be observed for 13, therefore $\mathbf{1 3}$ was reduced into the corresponding alcohol with $\mathrm{NaBH}_{4}$; Calcd. for $\mathrm{C}_{14} \mathrm{H}_{22} \mathrm{O}_{5} \mathrm{Na}[\mathrm{M}+\mathrm{Na}]^{+}: 293.1359$, found: 293.1355.

Optical purity of the product was determined by GC, under the conditions described in the General Experimental. For compound (-)-13, column temperature was linearly programmed from $40{ }^{\circ} \mathrm{C}$ to $100{ }^{\circ} \mathrm{C}$ at $0.4{ }^{\circ} \mathrm{C} / \mathrm{min}$, followed by $10{ }^{\circ} \mathrm{C} / \mathrm{min}$ from 100 to $233{ }^{\circ} \mathrm{C}$ (the final column temperature). Under these conditions the retention times of stereoisomers are: (-)-13-trans (minor enantiomer): $119 \mathrm{~min}$; (+)-13-trans (major enantiomer): $120 \mathrm{~min}$; 13-cis (major enantiomer): $127 \mathrm{~min}$; 13-cis (minor enantiomer): $127.5 \mathrm{~min}$.

\subsection{2. (-)-Trans-1-tosyl-4-vinylpyrrolidine-3-carbaldehyde (-)-14.}

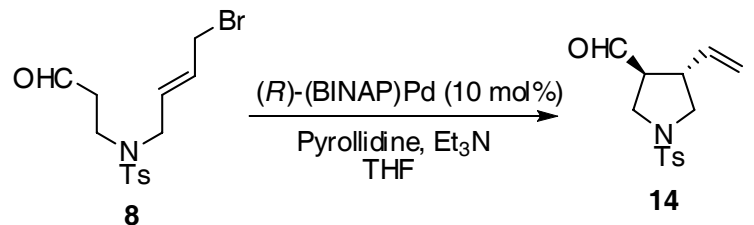

$0{ }^{\circ} \mathrm{C}, 8$ days: $27 \%, 59 \%$ ee

$(R)-(+)$-BINAP $(3.7 \mathrm{mg} ; 6 \mu \mathrm{mol})$ was added to a solution of $\mathrm{Pd}(\mathrm{OAc})_{2}(0.7 \mathrm{mg} ; 0.003$ $\mathrm{mmol})$ in THF $(0.28 \mathrm{~mL})$ and stirred under an argon atmosphere for $30 \mathrm{~min}$, while the solution turns orange. This solution was cooled to $0{ }^{\circ} \mathrm{C}$ and a solution of aldehyde 8 (15.3 $\mathrm{mg} ; 0.042 \mathrm{mmol})$ in THF $(0.28 \mathrm{~mL})$ was added, when the solution turned yellow. Pyrrolidine $(20 \mu \mathrm{L}$ of $0.44 \mathrm{M}$ solution in THF; $8 \mu \mathrm{mol})$ and $\mathrm{Et}_{3} \mathrm{~N}(5.9 \mu \mathrm{L} ; 0.042 \mathrm{mmol})$ were added, and the reaction mixture was stirred for 8 days at $0{ }^{\circ} \mathrm{C}$. On day two, additional pyrrolidine $(3.5 \mu \mathrm{L} ; 0.042 \mathrm{mmol})$ was added. On day four, additional $(R)-(+)-$ BINAP $(0.8 \mathrm{mg} ; 1 \mu \mathrm{mol})$, pyrrolidine $(20 \mu \mathrm{L}$ of $0.44 \mathrm{M}$ solution in THF; $8 \mu \mathrm{mol})$ and $\mathrm{Et}_{3} \mathrm{~N}(3 \mu \mathrm{L} ; 0.021 \mathrm{mmol})$ were added. On day seven, additional BINAP $(0.4 \mathrm{mg} ; 0.5$ $\mu \mathrm{mol})$, pyrrolidine $(10 \mu \mathrm{L}$ of $0.44 \mathrm{M}$ solution in THF; $4 \mu \mathrm{mol})$ and $\mathrm{Et}_{3} \mathrm{~N}(1.5 \mu \mathrm{L} ; 10$ $\mu \mathrm{mol})$. Concentration under reduced pressure, followed by purification by preparative TLC afforded $3.2 \mathrm{mg} \mathrm{(27 \% )}$ of the title compound (-)-14. 


\subsubsection{Determination of the optical purity of (-)-14}<smiles>C=C[C@@H]1CN(C)C[C@H]1C=O</smiles>

14<smiles>C=C[C@@H]1CN([As])C[C@@H]1CO</smiles>

26

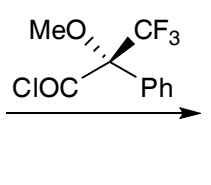<smiles>C=C[C@@H]1CN(C)C[C@@H]1COC(=O)[C@@](OC)(c1ccccc1)C(F)(F)F</smiles>

Aldehyde (-)-14 was reduced with $\mathrm{NaBH}_{4}$ to the corresponding alcohol 26, which was further converted into Mosher's ester 27. The optical purity of (-)-14 was determined by integrating ${ }^{19} \mathrm{~F}$ NMR signals of $\mathrm{CF}_{3}$ groups in stereoisomeric Mosher's esters 27.

\subsubsection{2. (Trans-1-tosyl-4-vinylpyrrolidin-3-yl)methanol 26}<smiles>C=C[C@@H]1CN(C)C[C@H]1C=O</smiles>

14<smiles>C=C[C@@H]1CN(S)C[C@@H]1CO</smiles>

26

$\mathrm{NaBH}_{4}(13.2 \mathrm{mg} ; 0.336 \mathrm{mmol})$ was added in two portions to a cold $\left(0{ }^{\circ} \mathrm{C}\right)$ solution of aldehyde 14 (46.8 $\mathrm{mg} ; 0.168 \mathrm{mmol})$ in a mixture of methanol $(2 \mathrm{~mL})$ and THF $(2 \mathrm{~mL})$, with stirring, under an argon atmosphere. After $15 \mathrm{~min}$, the reaction mixture was diluted with brine $(20 \mathrm{~mL})$ and extracted with EtOAc $(40 \mathrm{~mL}+30 \mathrm{~mL}+20 \mathrm{~mL})$. The organic extract was dried over anh. $\mathrm{MgSO}_{4}$, concentrated under reduced pressure and purified by column chromatography (eluent: $33 \%$ EtOAc in toluene) to give $33.7 \mathrm{mg}$ (71\%) of the title compound, as a brown liquid. Spectral data for 26: $\operatorname{IR}_{\text {film: }}$ : 3522, 3079, 2924, 2882, 1339, 1161, 1032, 815, 664. ${ }^{1} \mathrm{H}$ NMR: 7.66-7.62 (m, 2H), 7.28-7.24 (m, 2H), 5.57-5.40 $(\mathrm{m}, 1 \mathrm{H}), 5.00-4.92(\mathrm{~m}, 2 \mathrm{H}), 3.58-3.31(\mathrm{~m}, 4 \mathrm{H}), 3.07\left(\mathrm{dd}, J^{l}=9.8, J^{2}=8.2,1 \mathrm{H}\right), 2.89(\mathrm{t}, J$ $=9.2,1 \mathrm{H}), 2.48-2.24(\mathrm{~m}, 1 \mathrm{H}), 2.36(\mathrm{~s}, 3 \mathrm{H}), 2.08(\mathrm{~s}, 1 \mathrm{H}), 2.01-1.88(\mathrm{~m}, 1 \mathrm{H}){ }^{13} \mathrm{C} \mathrm{NMR}:$ $143.6(\mathrm{C}), 136.8(\mathrm{CH}), 133.4(\mathrm{C}), 129.7(\mathrm{CH}), 127.5(\mathrm{CH}), 117.2\left(\mathrm{CH}_{2}\right), 62.4\left(\mathrm{CH}_{2}\right), 52.6$ $\left(\mathrm{CH}_{2}\right), 50.5\left(\mathrm{CH}_{2}\right), 46.2(\mathrm{CH}), 44.7(\mathrm{CH}), 21.4\left(\mathrm{CH}_{3}\right)$. HRMS (ESI): calcd. for $\mathrm{C}_{14} \mathrm{H}_{20} \mathrm{NO}_{3} \mathrm{~S}[\mathrm{M}+\mathrm{H}]^{+}:$282.1158, found: 282.1162 . (-)-(Trans-1-tosyl-4-vinylpyrrolidin3-yl)methanol, (-)-26 was prepared according to the same procedure, from (-)-14, $[\alpha]_{589}$ -15.0 ( c 1, EtOAc). 


\subsubsection{Mosher's ester of Trans-1-tosyl-4-vinylpyrrolidin-3-yl)methanol 27}<smiles>C=C[C@@H]1CN([As])C[C@@H]1CO</smiles>

26

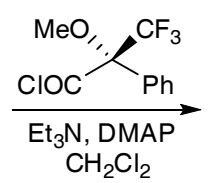

$\mathrm{CH}_{2} \mathrm{Cl}_{2}$

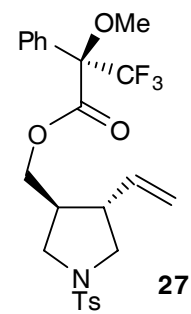

Oxallyl chloride $\left(100 \mu \mathrm{L}\right.$ of $0.57 \mathrm{M}$ solution in $\left.\mathrm{CH}_{2} \mathrm{Cl}_{2} ; 0.057 \mathrm{mmol}\right)$ was added to a solution of $(R)$ - $\alpha$-methoxy- $\alpha$-(trifluoromethyl)phenylacetic acid $(14.8 \mathrm{mg} ; 0.064 \mathrm{mmol}$ ) in $\mathrm{CH}_{2} \mathrm{Cl}_{2}(100 \mu \mathrm{L})$, with stirring under an argon atmosphere. A drop of DMF was added and the mixture was stirred for $30 \mathrm{~min}$ after the evolution of bubbles stopped. This solution is added to a solution of $26(5.2 \mathrm{mg} ; 18 \mu \mathrm{mol})$, DMAP $(0.3 \mathrm{mg})$ and $\mathrm{Et}_{3} \mathrm{~N}(33$ $\mu \mathrm{L} ; 0.235 \mathrm{mmol})$ in $\mathrm{CH}_{2} \mathrm{Cl}_{2}(180 \mathrm{~mL})$, and the resulting mixture was stirred for $1 \mathrm{~h}$. The reaction mixture was diluted with $\mathrm{CH}_{2} \mathrm{Cl}_{2}$, washed with aq. $1 \mathrm{M} \mathrm{HCl}$ and sat. $\mathrm{NaHCO}_{3}$, dried over anh. $\mathrm{MgSO}_{4}$ and concentrated under reduced pressure. Purification by column chromatography (eluent: $33 \%$ EtOAc in petroleum ether) afforded $7.6 \mathrm{mg}(83 \%)$ of the title compound as a colorless, viscous oil. Mosher's ester of the optically enriched (-)-26 was obtained according to the same procedure. Spectral data for 27: $\operatorname{IR}_{\text {film: }}$ : 3064, 2952, 2851, 1751, 1165, 1023, 664. ${ }^{1} \mathrm{H}$ NMR: 7.69-7.66 (m, 2H), 7.46-7.39 (m, 5H), 7.34-7.29 $(\mathrm{m}, 2 \mathrm{H}), 5.55-5.45(\mathrm{~m}, 1 \mathrm{H}), 5.08-4.97(\mathrm{~m}, 2 \mathrm{H}), 4.34\left(\mathrm{dd}, J^{l}=11.3, J^{2}=4.2,1 \mathrm{H}\right.$, OC $\mathbf{H}_{\mathrm{a}} \mathrm{H}_{\mathrm{b}^{-}}$, trans, major isomer), $4.25\left(\mathrm{dd}, J^{l}=11.3, J^{2}=4.2,1 \mathrm{H}, \mathrm{OCH}_{\mathrm{a}} \mathrm{H}_{\mathrm{b}^{-}}\right.$, trans, minor isomer), $4.18\left(\mathrm{dd}, J^{l}=11.2 \mathrm{~Hz}, J^{2}=6.3 \mathrm{~Hz}, 1 \mathrm{H}, \mathrm{OCH}_{\mathrm{a}} \mathrm{H}_{\mathrm{b}^{-}}\right.$, cis, major), $4.13\left(\mathrm{dd}, J^{l}=\right.$ 11.3, $J^{2}=7.1,1 \mathrm{H}, \mathrm{OCH}_{\mathrm{a}} \mathbf{H}_{\mathbf{b}^{-}}$, trans, minor), $4.04\left(\mathrm{dd}, J^{l}=11.3, J^{2}=7.4,1 \mathrm{H}, \mathrm{OCH}_{\mathrm{a}} \mathbf{H}_{\mathbf{b}^{-}}\right.$, trans, major), $3.99\left(\mathrm{dd}, J^{l}=11.1, J^{2}=8.1,1 \mathrm{H}, \mathrm{OCH}_{\mathrm{a}} \mathbf{H}_{\mathbf{b}^{-}}\right.$, cis, major), 3.89 (dd, $J^{l}=11.2$, $J^{2}=8.5,1 \mathrm{H}, \mathrm{OCH}_{\mathrm{a}} \mathbf{H}_{\mathbf{b}^{-}}$, cis, minor), (the overall integral in the region 4.35-3.87 corresponds to $2 \mathrm{H}), 3.52-3.43(\mathrm{~m}, 5 \mathrm{H}), 3.04-2.98(\mathrm{~m}, 2 \mathrm{H}), 2.44-5.43(\mathrm{~m}, 3 \mathrm{H}), 2.40-2.34$ $(\mathrm{m}, 1 \mathrm{H}), 2.20-2.12(\mathrm{~m}, 1 \mathrm{H}) .{ }^{13} \mathrm{C}$ NMR for the trans-isomers: 165.3, 143.7, 135.6 (major), 135.5 (minor), 133.4, 131.8, 129.8, 129.7, 128.5, 127.5, 127.2, 123.2 (q, $J=287.5$ ), 118.3, 84.7 (minor), 84.5 (major), 65.1 (major), 64.9 (minor), 55.4, 52.41 (minor), 52.36 (major), 50.3, 45.0 (major), 44.9 (minor), 43.1 (minor), 43.0 (major), 21.5. ${ }^{19} \mathrm{~F}$ NMR: 71.43 (minor cis-isomer), 71.46 (trans, major), 71.48 (cis, major), 71.54 (trans, minor). HRMS (ESI): calcd. for $\mathrm{C}_{24} \mathrm{H}_{27} \mathrm{~F}_{3} \mathrm{NO}_{5} \mathrm{~S}[\mathrm{M}+\mathrm{H}]^{+}: 498.1556$, found: 498.1558 .

The cis/trans ratio of the product was determined from ${ }^{1} \mathrm{H}$ NMR, according to the formula: 27 trans $/ 27$ cis $=[\operatorname{Integ}(4.13 \mathrm{ppm})+\operatorname{Integ}(4.04 \mathrm{ppm})] /[\operatorname{Integ}(3.99 \mathrm{ppm})+$ Integ $(3.89 \mathrm{ppm})]$. For the racemic 27: trans $/$ cis=10/1. For the optically enriched 27: trans/cis $=9 / 1$. The optical purity of $\mathbf{1 4}$ was determined from ${ }^{19} \mathrm{~F}$ NMR of 27 , by integrating peaks correspondindg to $\mathrm{CF}_{3}$ groups in stereoisomeric Mosher's esters 27, and was found to be $59 \%$ ee. 


\section{References}

${ }^{1}$ For description of the technique of dry-flash chromatography, see: a) Harwood, L. M. Aldrichimica Acta 1985, 18, 25; b) Vogel's Textbook of Practical Organic Chemistry, Longman Scientific\&Technical, $5^{\text {th }}$ edition, London, 1989, p. 220; c) A recent account which includes some improvements of the separation technique: Pedersen, D. S.; Rosenbohm, C. Synthesis 2001, 2431.

${ }^{2}$ Perrin, D. D.; Armarego, W. L. F. Purification of Laboratory Chemicals, $3^{\text {rd }}$ edition, Pergamon Press, 1988.

${ }^{3}$ A. Ivkovic, R. Matovic, R. N. Saicic, J. Serb. Chem. Soc. 2002, 67, 141.

${ }^{4}$ a) K. Beatig, C. Dallaire, R. Pitteloud, P. Deslongchamps, Tetrahedron Lett. 1987, 28, 5249;

b) A. Marinier, K. Beatig, C. Dallaire, R. Pitteloud, P. Deslongchamps, Can. J. Chem. 1989, 67, 1609.

${ }^{5}$ R. E. Claus, S. L. Schreiber, Org. Synth. Coll. Vol. 7, 168.

${ }^{6}$ R. C. Crumbie, J. S. Nimitz, H. S. Mosher, J. Org. Chem. 1982, 47, 4040.

${ }^{7}$ S. L. Schreiber, R. E. Claus, J. Reagan, Tetrahedron Lett. 1982, 23, 3867; S. L. Schreiber, S. E. Kelly, J. A. Porco, T. Sammakia, E. M. Suh, J. Am. Chem. Soc. 1988, 110, 6210.

${ }^{8}$ With pyrrolidine loading lower than $30 \%$ the conversion was often incomplete. With more than 1 eq of pyrrolidine in the reaction mixture quaternization becomes a serious side reaction.

${ }^{9}$ M. Yoshitake, M. Yamamoto, S. Kohmoto, K. Yamada, J. Chem. Soc. Perkin Trans. 1 1991, 2161.

${ }^{10}$ I. Ibrahem, A. Cordova, Angew. Chem. Int. Ed. 2006, 45, 1952; Angew. Chem. 2006, 118, 1986. 
PULSE SEOUEMCE

PULSE SEQUENCE
Relax. de lay arrayed

1st pulse arrayed
2nd pulse 90.0 degrees

Acq. $t$ ime $2.859 \mathrm{sec}$

Arrayed repetit

OBSERVE H1, $199.9710914 \mathrm{MHZ}$

OATA PROCESSING $0.2 \mathrm{~Hz}$

FT size 32768 ing

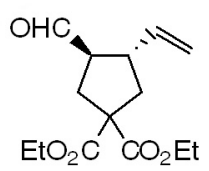

13

$1 \mathrm{H}$ NMR

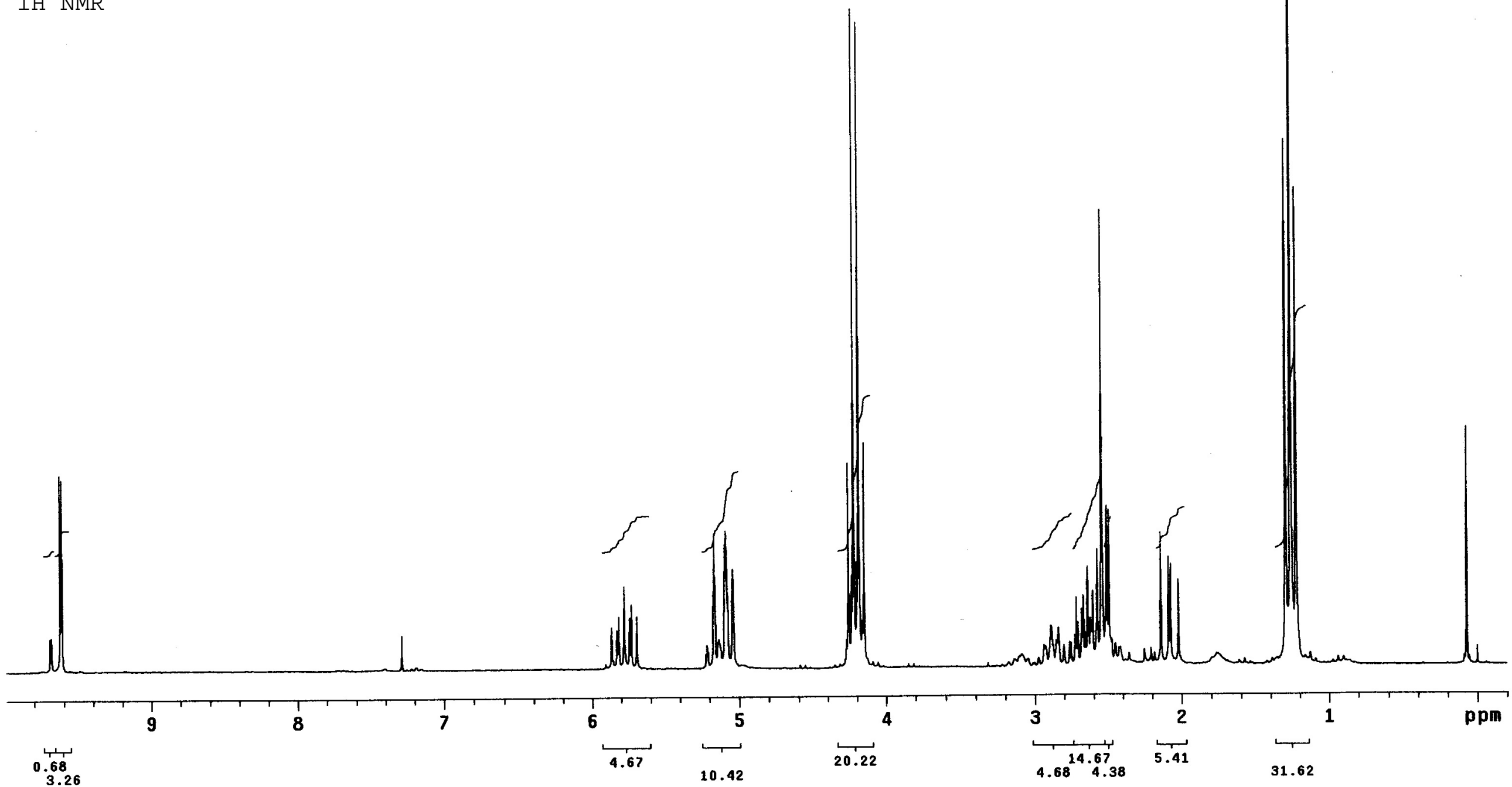


PULSE SEQUENCE: apt
Relax. delay arrayed

1st puise arrayed

2nd pulse 122 . ᄀ degrees

Acq $t$ time 2.000 sec

Arrayed repet it ions
OBSERVE C13, 50.2827794

DECOUPLE H1, 199.9712807 MHZ

Power 0 dB

WALTZ-16 modulated

DATA PROCESSING $2.0 \mathrm{HZ}$

Line broaden

fT size 65536 a

$13 \mathrm{C}$ NMR

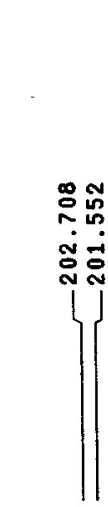

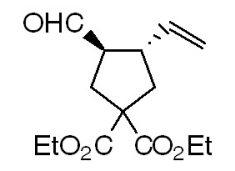

13

(1)
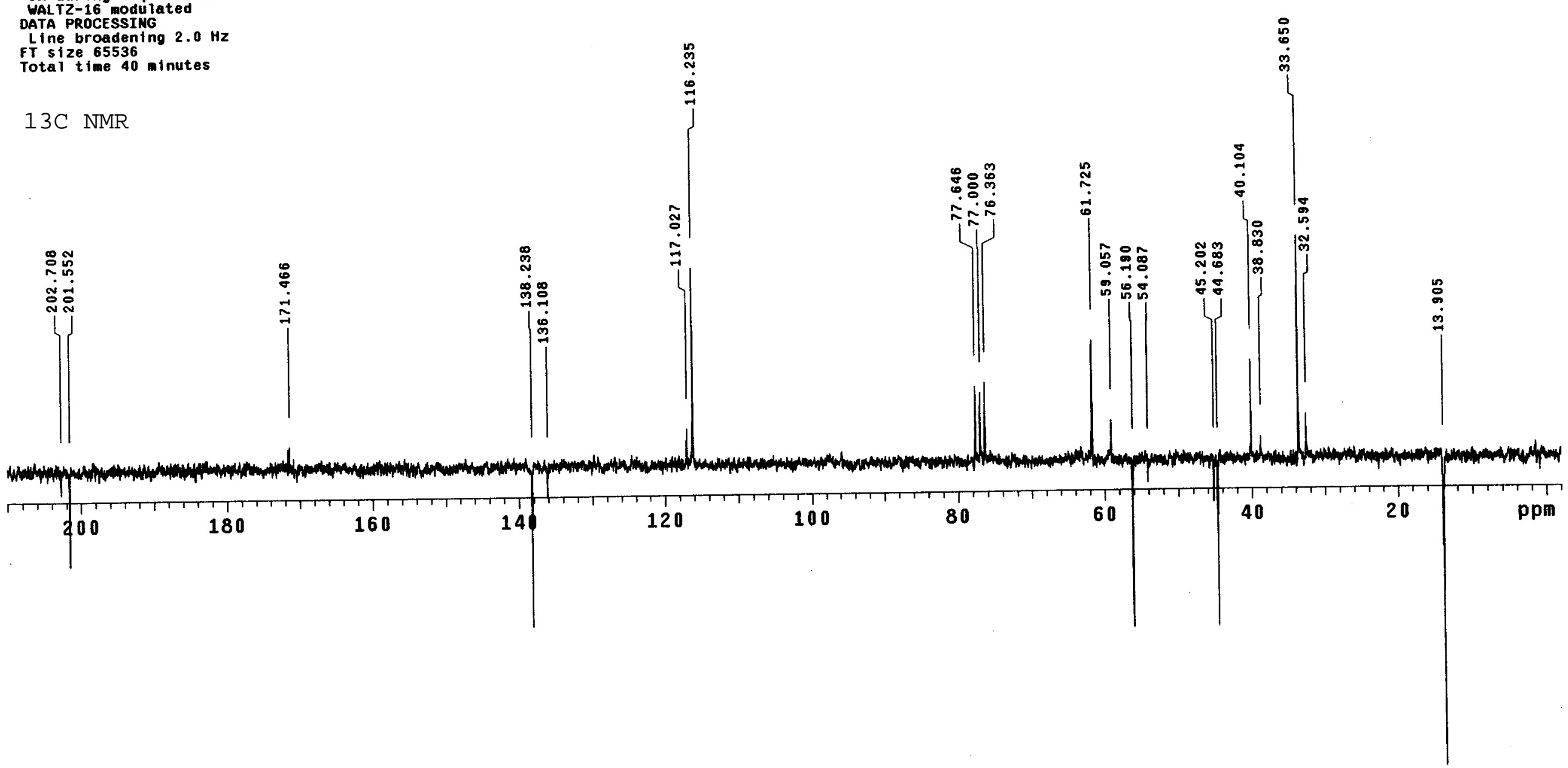


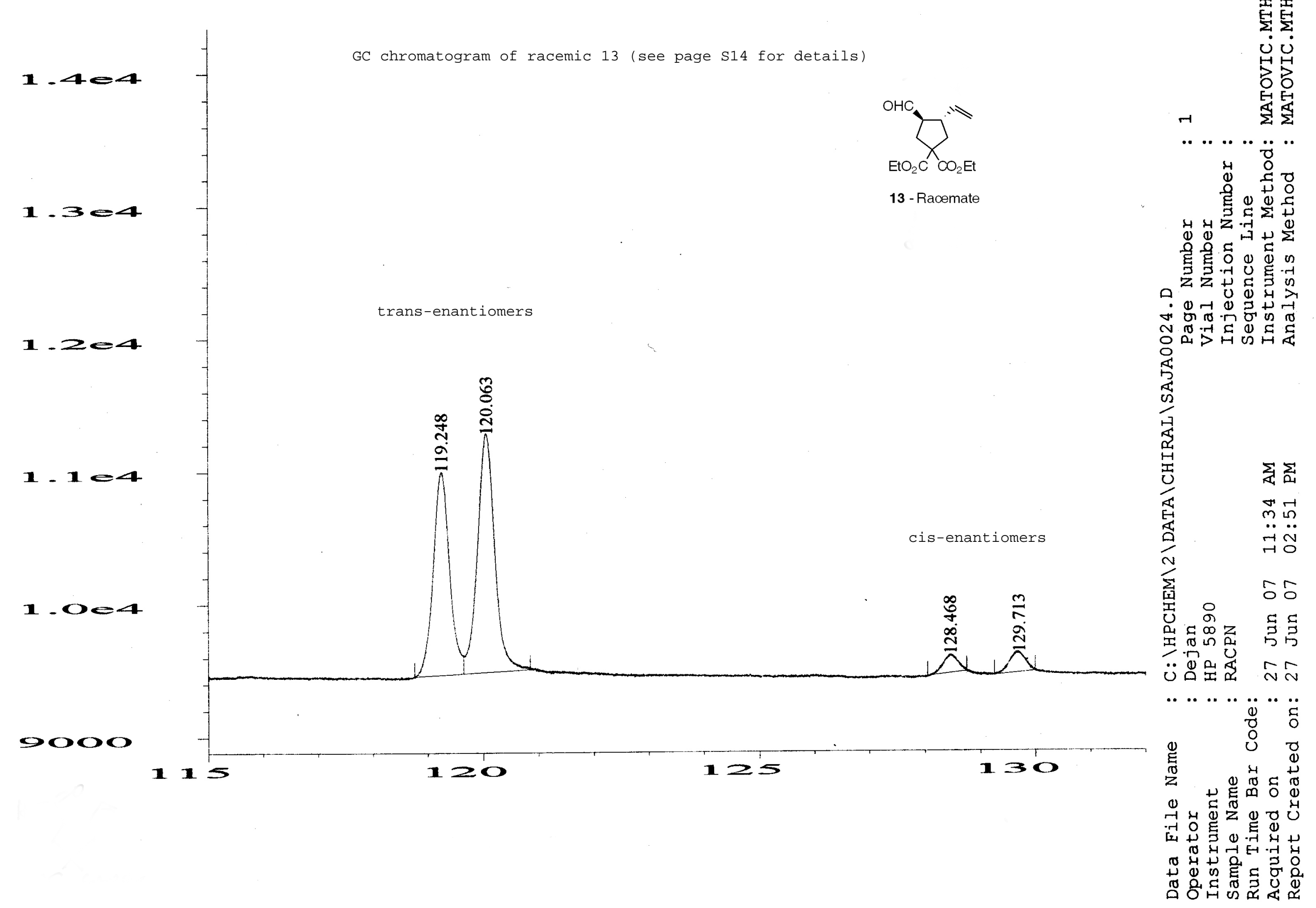




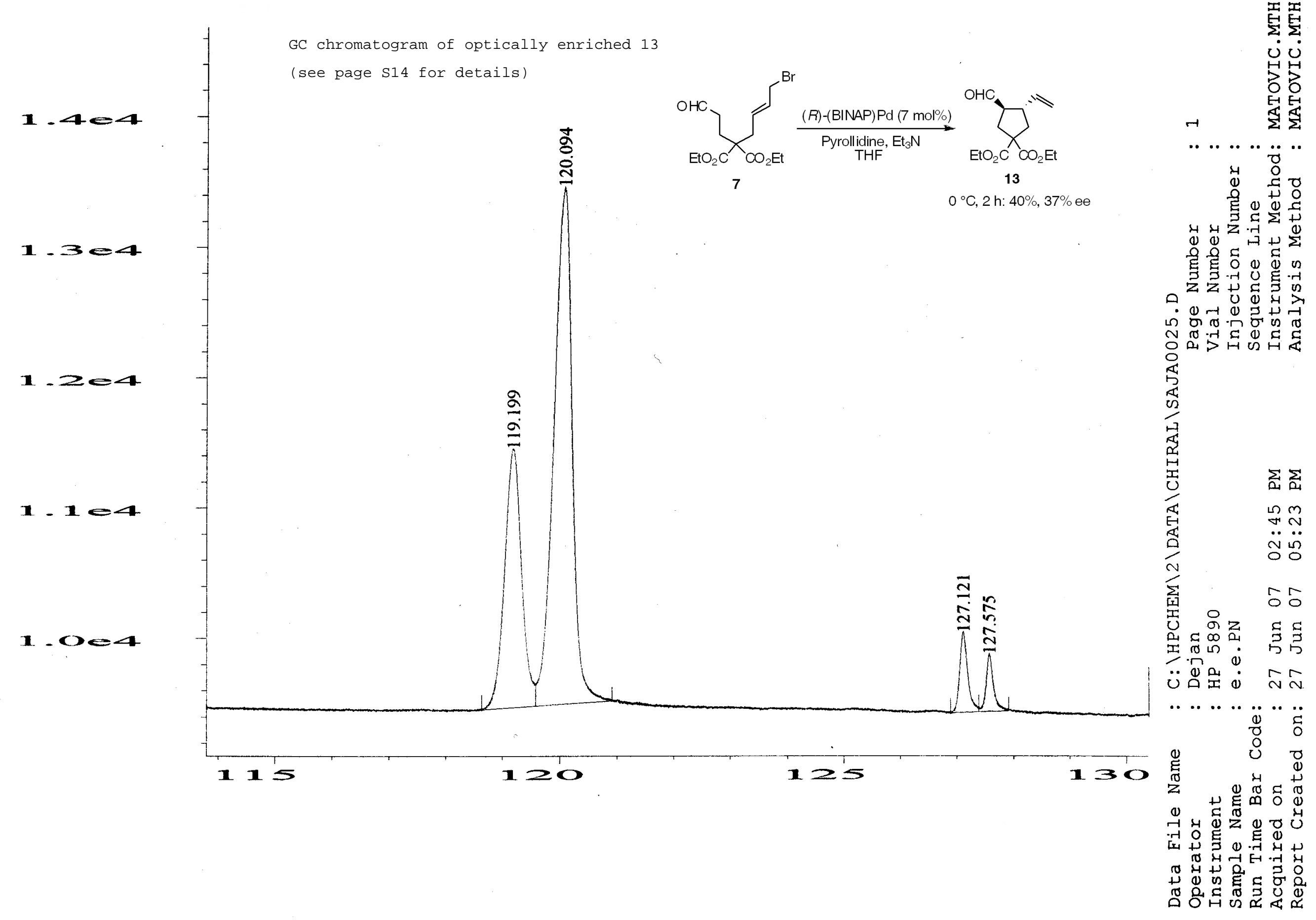




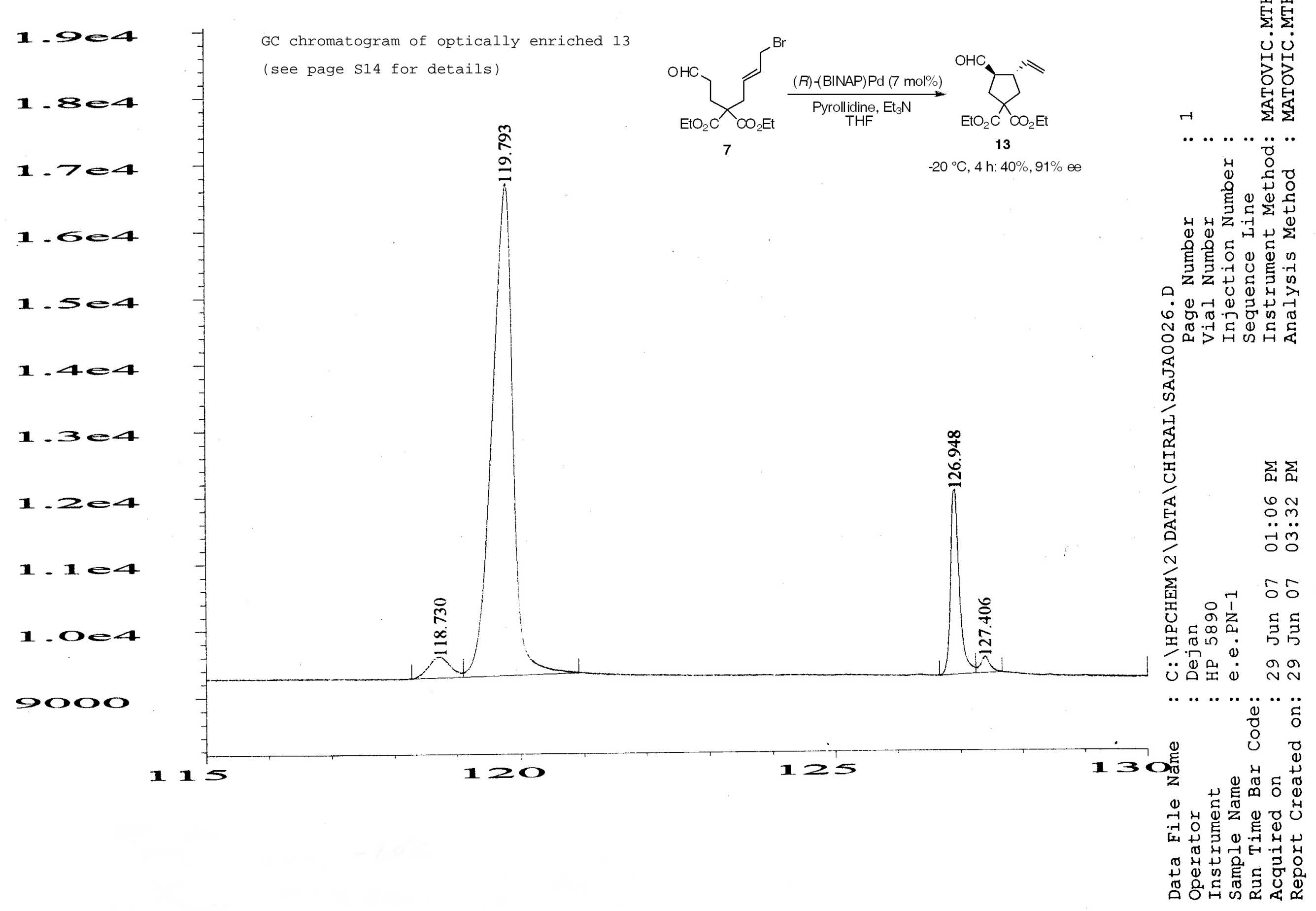


BV-I-020

Solvent: $\mathrm{cdcl} 3$

Ambient temperaturo

PULSE SEQUEMCE

Relax. de lay arrayed

2nd pulse go.0 degres

Acq tine $3,476 \mathrm{sec}$

Width $3198.7 \mathrm{~Hz}$

OQSERVE H1, 199.9710957

ATA PROCESSIMG

FT ine broadening $0.2 \mathrm{~Hz}$

Total time

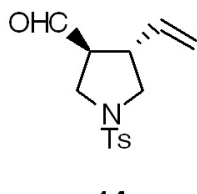

14

1H NMR

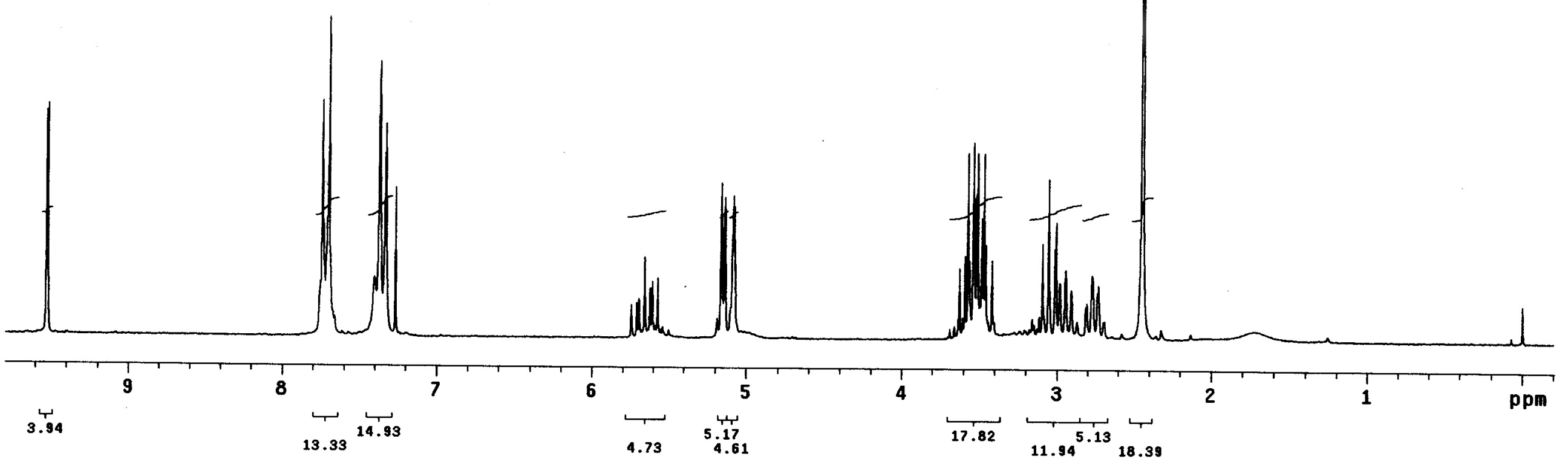


BV-I-020

Solvent: cdcls

Anbient temperature
GEMIMI-200 "nar"

PULSE SEQUEMCE : apt

Re lax. de lay arrayed

2nd pulse 122.7 degrees

Acq $t$ tiee $2.000 \mathrm{sec}$

Arrayed repet it

OBSERVE C13, 50.2827780 MHz

POWET OH1, 199.9712807 MHZ

on during acquisition

WAL P-16 adulated

Line broadening $0.5 \mathrm{~Hz}$

Total time 109 minutes

13C NMR

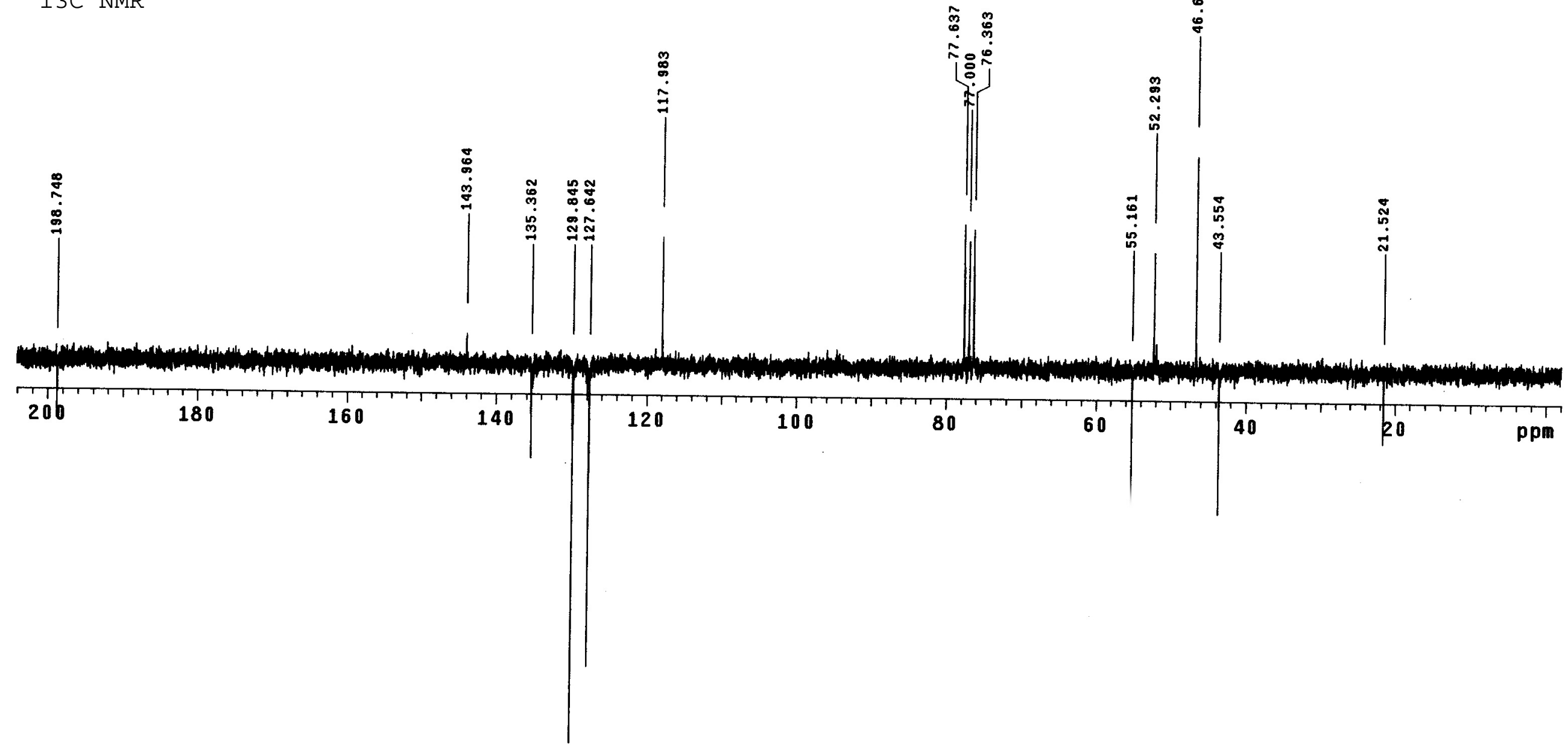


FB-I-240

GEMINI -200 temperature

PULSE SEQUEMCE

Relax. de lay arrayed

2nd pulse go gued

Acq. time $2.073 \mathrm{sec}$

Width $4600.0 \mathrm{~Hz}$

ABSERVE repet tions 10971 HIZ

DATA PROCESSIMG . 120971 MHZ

Line broadening $0.2 \mathrm{~Hz}$

FT 512 ze 32768
Total time 3 minutes

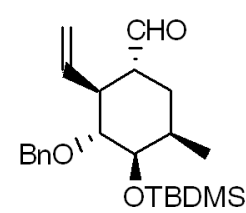

16

1H NMR

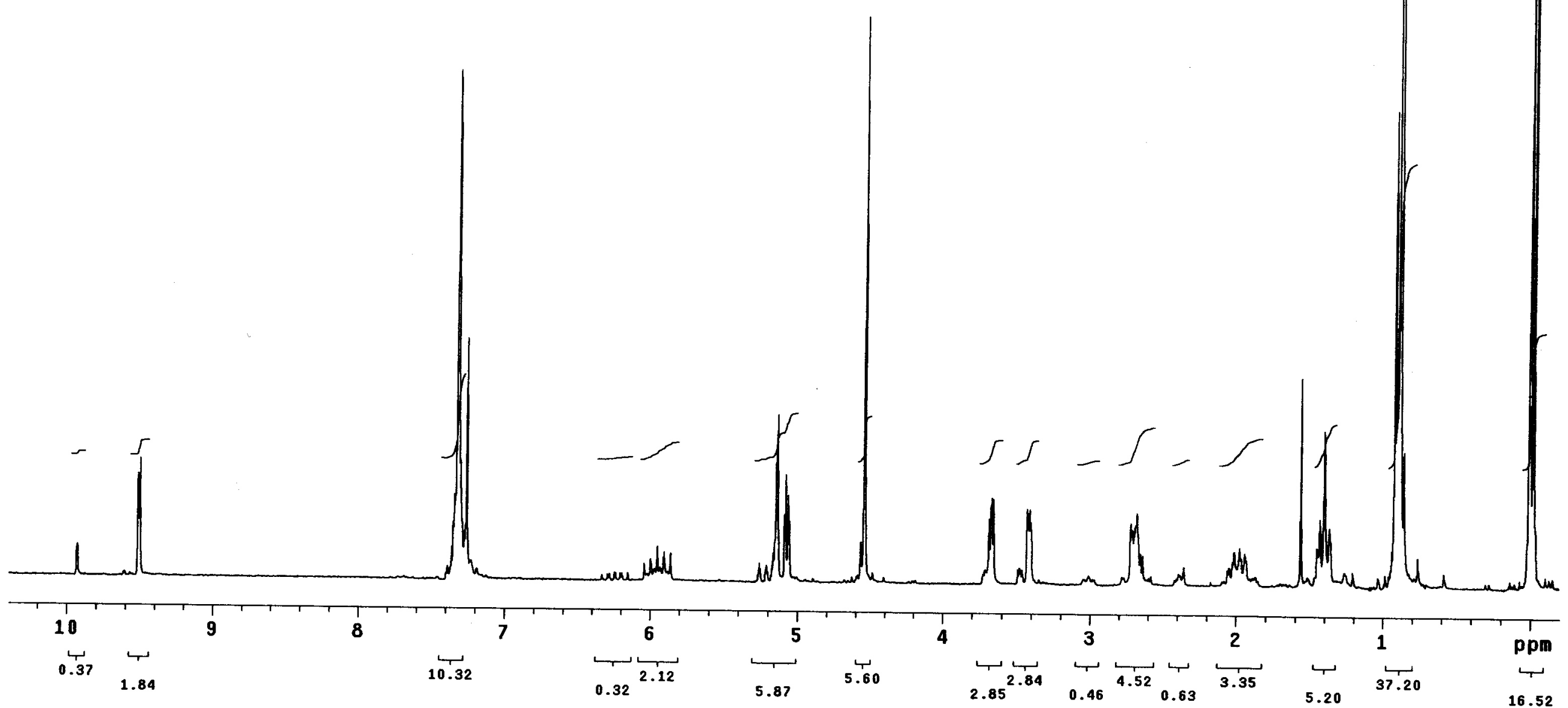


FB-I-133

Solvent: $\operatorname{coc} 13$

Aabient temperature

PULSE SEQUEMCE: APE

Relax. delay arrayed

1st pulse arrayed

2nd pulse 122.7 degrees

vidith $15000.0 \mathrm{~Hz}$

arrayed repeit

ObSERVE C13, 50.2827789 MHZ

Power o dB , 190.97

on during acquis 1 t ton

WALTZ-16 modulated

DATA PROCESSIMG $2.0 \mathrm{~Hz}$

FT size 65536 . 2.0

13C NMR

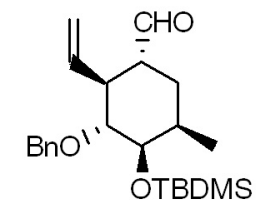

16

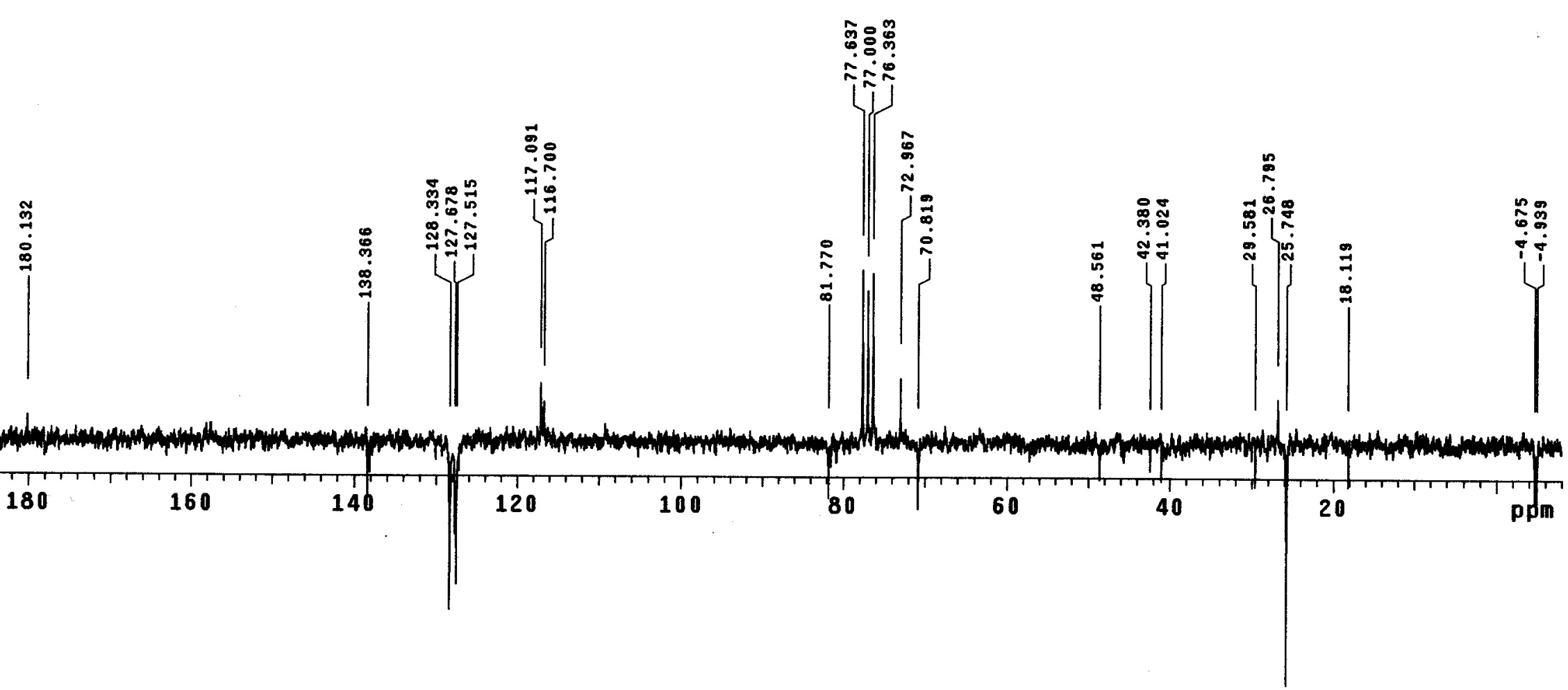




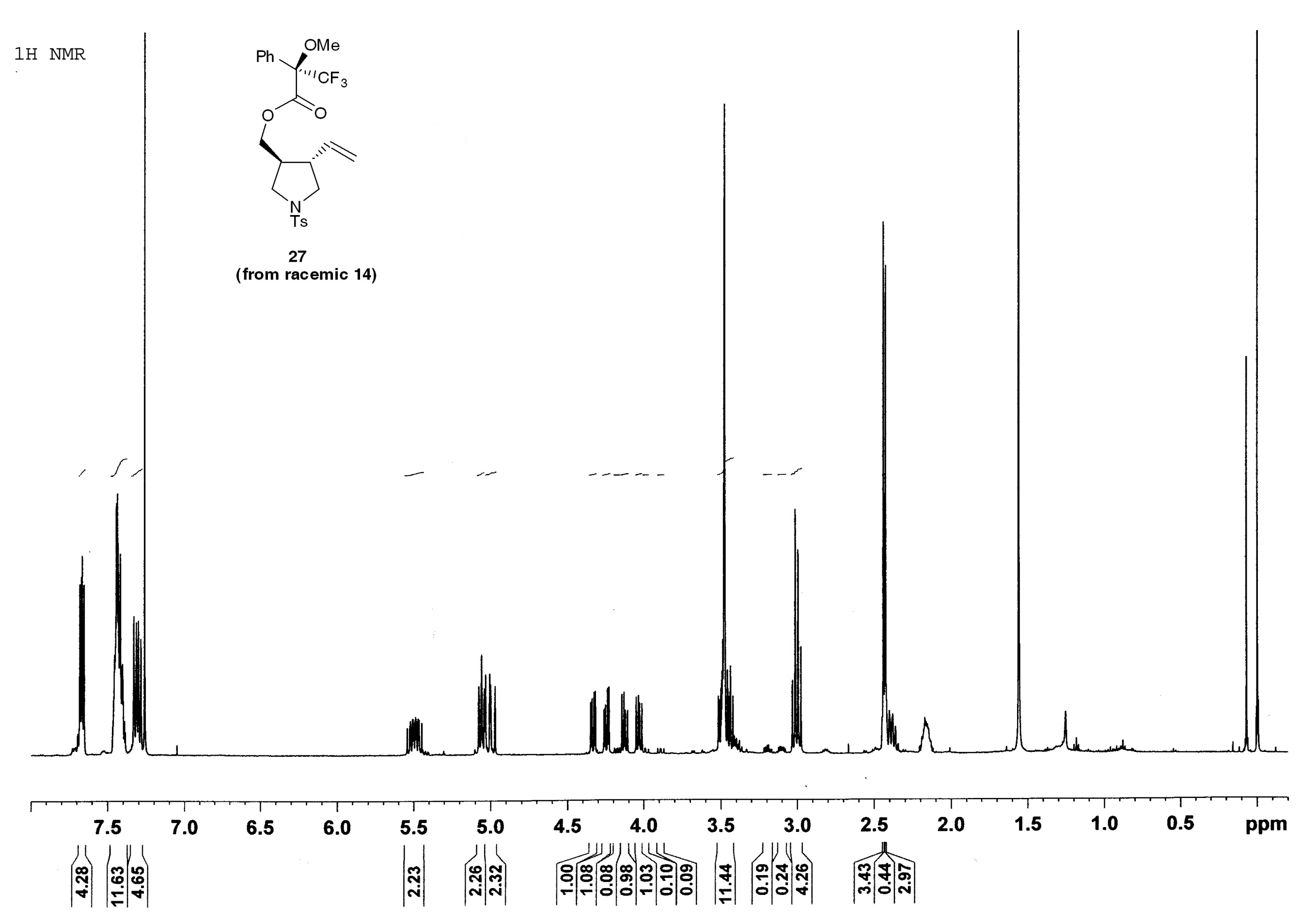




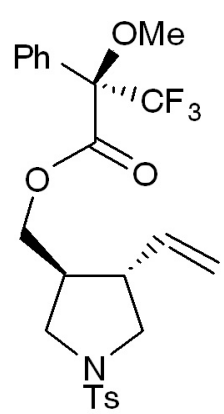

27

(from optic ally enriched 14)

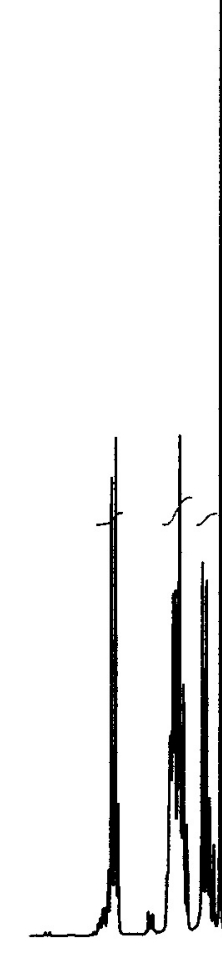

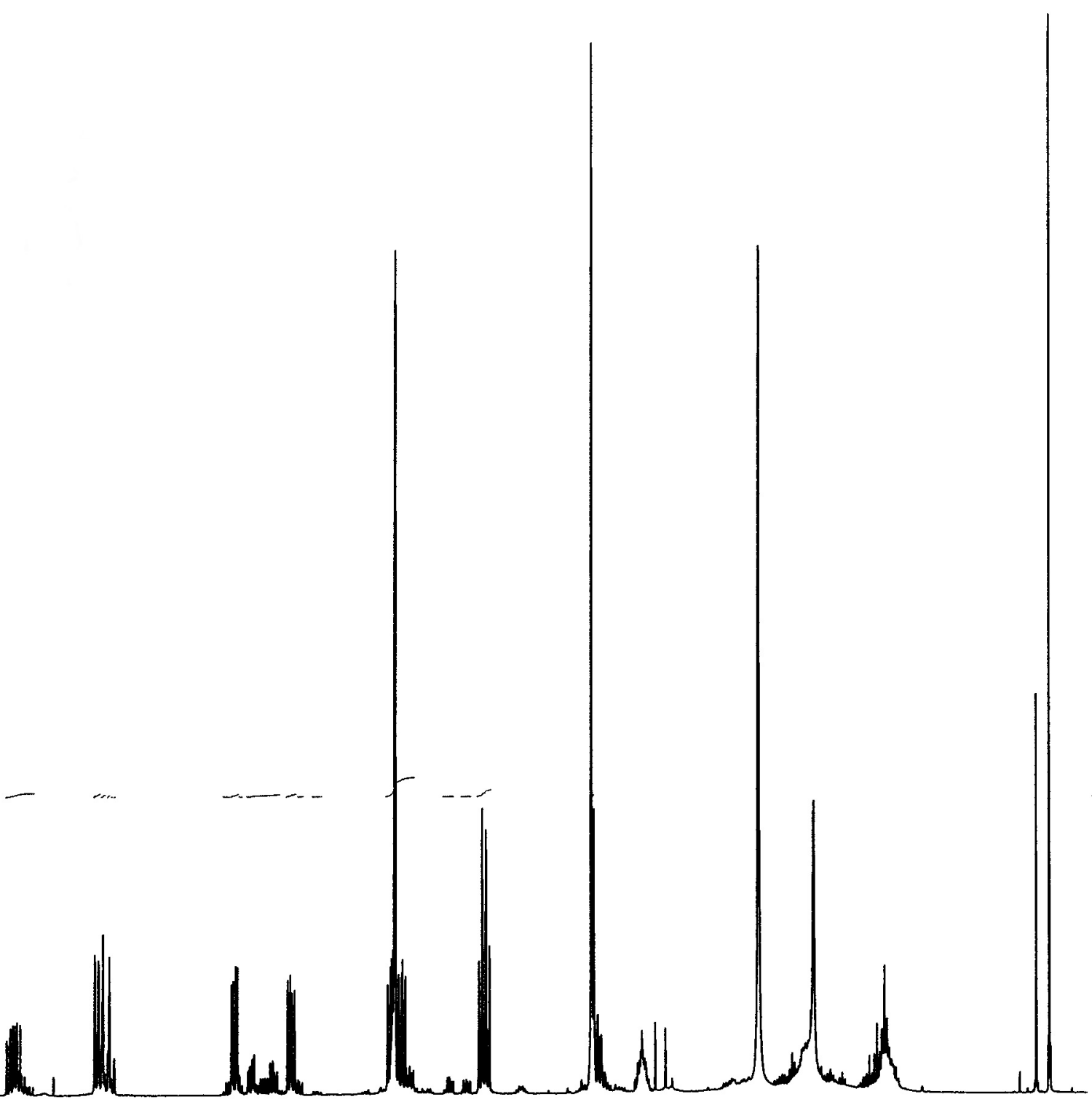

Current Data Parameters

NAME
EXPNO
PROCNO

F2 - Accuisition parameter

F2 - Acquisition Paramete
Date_ 20070801

$\begin{array}{lr}\text { Time } & 15.35 \\ \text { INSTRUM } & \text { spect } \\ \text { PROBHD } & \text { mm BBO BB-11H }\end{array}$

PULPROG

SOLVEN

NS

128
0

$\begin{array}{ll} & 5980.861 \mathrm{~Hz} \\ \text { IDRES } & 0.091261 \mathrm{~Hz}\end{array}$

$\begin{array}{lr}\text { AQ } & 5.4788594 \mathrm{sec} \\ \text { RG } & 362\end{array}$

$\begin{array}{lr}\mathrm{DN} & 83.600 \text { usec } \\ \mathrm{DE} & 6.50 \text { usec }\end{array}$

$\begin{array}{ll}\text { TE } & 1.00000000 \mathrm{Kec} \\ \mathrm{D} 1 & \end{array}$

$===== \pm==$ CHANNEL
NUC1 $=======$

$\begin{array}{ll}\text { NUC1 } & 1 \mathrm{H} \\ \text { P1 } & 9.35 \text { usec } \\ \text { PL1 } & 0.00 \mathrm{~dB}\end{array}$

$500.2620165 \mathrm{MH}$

F2 - Processing parameters

SI 32768

WDW $\quad 500.2600081$ MHz

$\begin{array}{ll}\text { WSW } & 0 \\ \text { IB } & 0.20 \mathrm{~Hz} \\ \text { GB } & 1.00 \\ \text { PC } & \end{array}$

$\mathrm{GB}$
$\mathrm{PC}$

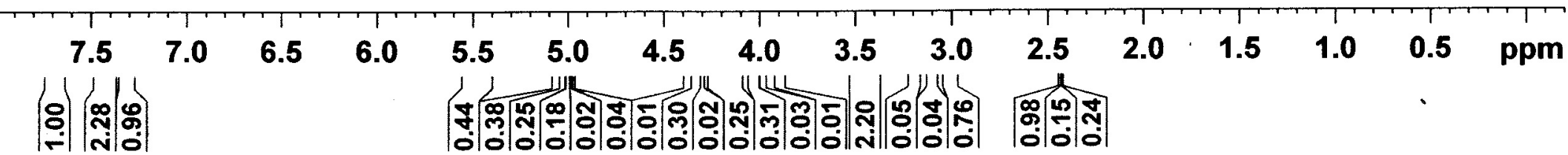


19F NMR<smiles>C=C[C@@H]1CN([As])C[C@@H]1COC(=O)[C@](OC)(c1ccccc1)C(F)(F)F</smiles>

27 (from racemic 14)

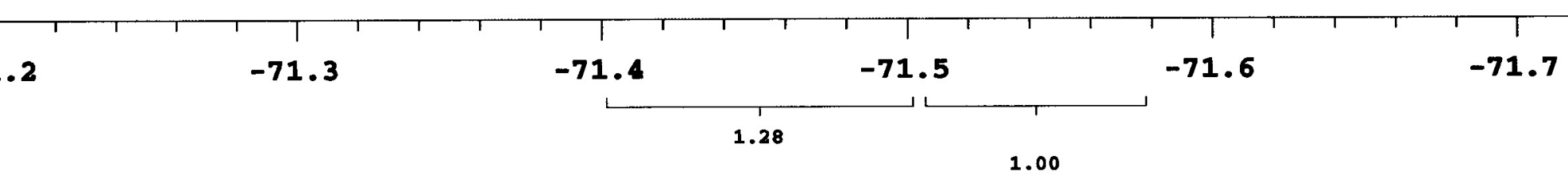




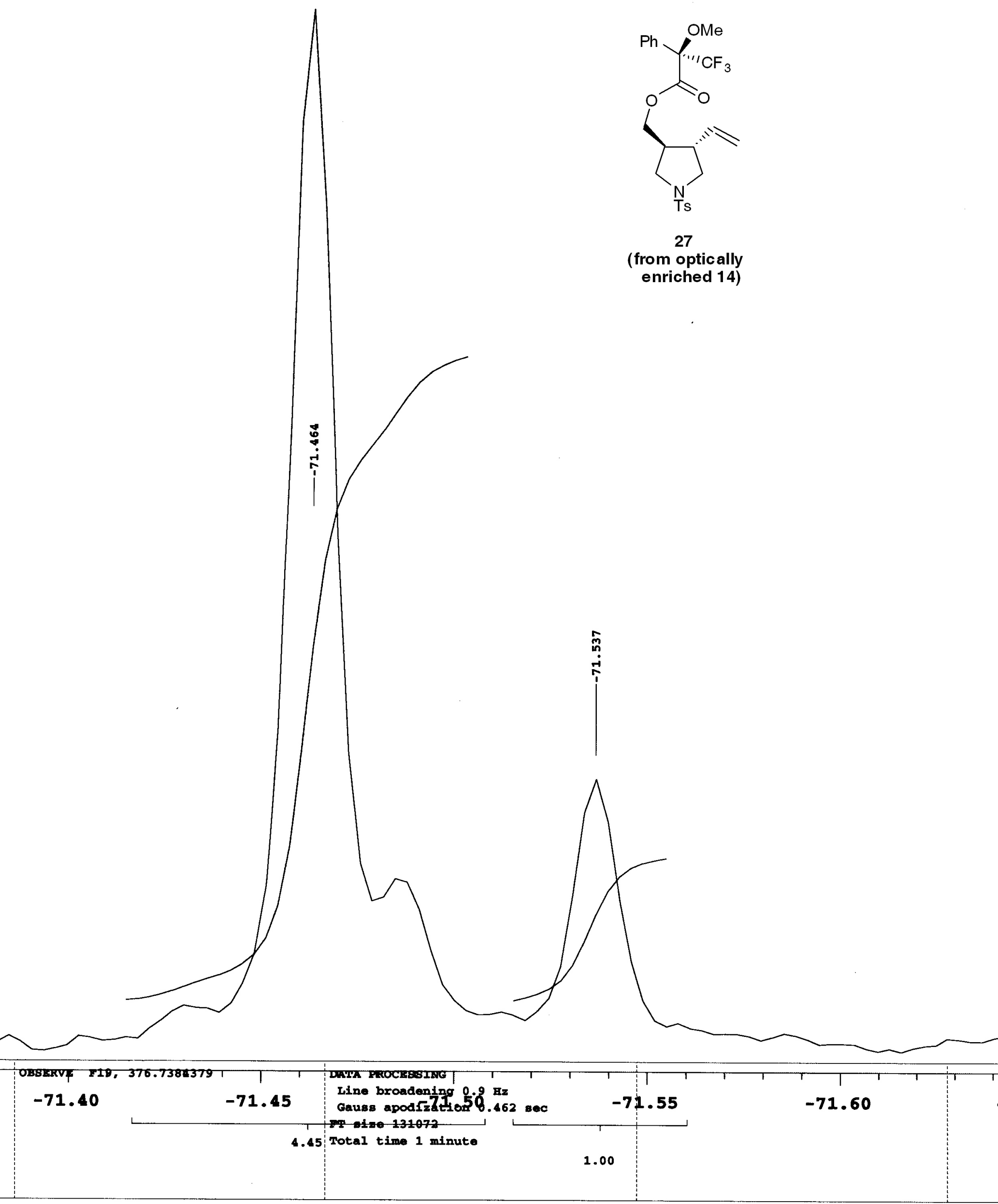

